\title{
Fossil Fuel Prices and the Economic and Budgetary Challenges of a Small Energy-Importing Economy: The Case of Portugal ${ }^{*}$
}

\author{
Alfredo Marvão Pereira** \\ The College of William and Mary \\ Rui M. Pereira \\ University of the Algarve \\ College of William and Mary \\ Department of Economics \\ Working Paper Number 115 \\ Previous Version: April 2011 \\ This Version: May 2013
}

\footnotetext{
${ }^{(*)}$ This paper is part of a project financed by the Fundação de Ciência e Tecnologia do Ministério de Ciência e Tecnologia, Portugal, reference number: PTDC/ECO/72065/2006. An early version of this paper was presented at the $4^{\text {th }}$ International Meeting of the Portuguese Economic Journal. We would like to thank an anonymous referee for very detailed and thoughtful comments and suggestions.
} 
COLLEGE OF WILLIAM AND MARY

DEPARTMENT OF ECONOMICS

WORKING PAPER \# 115

May 2013

\title{
Fossil Fuel Prices and the Economic and Budgetary Challenges of a Small Energy-Importing Economy: The Case of Portugal
}

\begin{abstract}
: This paper examines the economic and budgetary impacts of fuel prices using a dynamic general equilibrium model of the Portuguese economy which highlights the mechanisms of endogenous growth and includes a detailed modeling of the public sector. The fuel price scenarios are based on forecasts by the US Department of Energy (DOE-US) and the International Energy Agency (IEA-OECD) and represent a wide range of projections for absolute and relative fossil fuel prices. In terms of the long term economic impact, our results suggest a 1.9 percent drop in GDP in the DOE-US scenario and 1.6 percent in the IEA-OECD scenario. As to the budgetary impact, higher fuel prices lead to lower tax revenues, which, coupled with a reduction in public spending, translate into lower public deficits. Accordingly, increasing fuel prices create an important policy trade off in that they can contribute to reducing the public deficit while hindering economic growth. We find that fairly strong incentives for wind energy can reduce the economic impact of fuel prices by 14.2 percent in the DOE-US price scenario and 18.5 percent reduction in the IEA-OECD price scenario. Finally, our results highlight the importance of public sector spending decisions and the mechanisms of endogenous growth in understanding the impact of fossil fuel prices. Indeed, a scenario of higher fuel prices would, with exogenous public decisions and exogenous economic growth assumptions, result in substantially smaller economic effects and yield adverse budgetary effects.
\end{abstract}

Keywords: Fuel Prices, Economic Performance, Budgetary Consolidation, Dynamic General Equilibrium, Endogenous Growth, Portugal.

JEL Classifications: C68, D58, H50, H60, O52, Q43.

Alfredo Marvão Pereira

Department of Economics,

The College of William and Mary, Williamsburg, USA

PO Box 8795, Williamsburg, VA 23187

ampere@,wm.edu

Rui M. Pereira

Dept. of Economics

University of the Algarve

Faro, Portugal

rui.marvao.pereira@gmail.com 


\section{Introduction}

A great deal of empirical research has highlighted the dynamic relationship between energy prices, energy consumption and economic growth [see, for example, Jorgenson (1998), Hamilton (2003, 2009), He et al. (2010), Korhonen and Ledyaeva (2010), and Tang et al. (2010)]. The literature explores the way in which fossil fuel prices affect economic activity and the mechanisms driving these effects [see, for example, Bruno and Sachs (1985), Backus and Crucini (2000), Brown and Yücel (2002), Esteves and Neves (2004), Sousa (2011)]. What seems to be abundantly clear from this literature is that energy has an important economic impact. As a result, energy prices are acknowledged as an important input for macroeconomic forecasting [see, for example, Esteves and Coimbra (2004), Roeger (2005) and EC (2010)].

The basic mechanism through which imported energy prices affect the economy is through the demand for energy as a basic input to production, with the subsequent implications for private investment, labor demand and the overall input mix. In addition, changes in the firms' profitability affect household income, and domestic consumption and savings decisions. These demand responses, in turn, shape the impact of imported energy prices on trade imbalances. Although several other channels have been considered in the literature, the influence of energy as an input to production has been recognized as contributing the most towards explaining the impact of fuel prices on economic performance [see, for example, Borges and Goulder (1984) and Brown and Yücel (2002)]. Indeed, the impact of oil price shocks on a small, oil-importing developing economy has been shown to depend critically on the production structure of the economy [see Schubert and Turnovsky (2010)].

We focus on the effects of fuel prices on the public sector behavior and account, something that has been largely absent from the literature. Imported fossil fuel prices affect 
economic performance both in terms of economic growth and of its dynamic feedbacks with the public sector. By affecting economic growth and activity levels, fuel prices affect the size of the tax base and the cost of public funds. This means that any serious forecast of tax revenues has to consider the effects of changing fuel prices. More importantly, by affecting the availability of public funds, fuel prices affect financing for productive public sector education and infrastructure spending, both of which can themselves contribute towards economic growth.

The link between economic growth and the public sector account is fundamental since it directly correlate to some of the most important policy constraints faced by many energyimporting economies in their pursuit of sound policies: the need to enact policies that promote long-term growth and fragile public budgets. These policy constraints are particularly relevant for the less developed energy-importing economies in the European Union (EU). As EU structural transfers have shifted towards new member states, countries such as Ireland, Greece, and Portugal have been forced to rely on domestic public policies to promote real convergence to EU standards of living. This poses a challenge since growing public spending and, more recently, falling tax revenues and countercyclical policies have contributed to a fast increasing public debt and a sharp need for budgetary consolidation. Furthermore, the need for fiscal responsibility is ever present in the context of the Stability and Growth Programs these countries are subject to in the framework of their participation in the Euro zone and much more so in presence of the EU and IMF led austerity plans these countries are facing.

The last ten years have seen substantial changes in the energy system in Portugal, marked by the introduction of natural gas and an increasing contribution of domestic renewable energy resources. Oil, however, remains the dominant energy vector in primary consumption. Domestic production of energy in Portugal is limited to wind and hydroelectric energy. As such, the degree 
of energy dependence in Portugal has always been substantially higher than that observed in the EU15, around 84 percent in the last three decades [see Amador (2010)]. This leaves the country in a position similar to that of many small, oil-importing economies faced with rising prices for imported energy.

The deployment of renewable energy technologies has been a major policy objective, contributing to increasing security of supply, through the diversification of energy sources, while reducing the environmental impacts associated with the energy system. In addition to examining the impact of fossil fuel prices on economic growth and the public sector account, we consider the potential for investment tax credits for the deployment of renewable energy infrastructure to offset the economic and budgetary impacts of energy prices in Portugal.

In this paper we explore the dynamic relationship between fossil fuel prices, economic performance and the public sector account. Our simulation results are based on a dynamic general equilibrium model which highlights the mechanisms of endogenous growth and provides a detailed specification of public sector activities, both tax revenues and consumption and investment spending. This model is applied to the Portuguese economy, an economy dependent on foreign energy sources and is calibrated to replicate the stylized facts of the Portuguese economy over several business cycles. Previous versions of this model have been used to evaluate the impact of tax policy [see Pereira and Rodrigues $(2002,2004)$ ], social security reform [see Pereira and Rodrigues (2007)] and, more recently, energy and environmental policy [see Pereira and Pereira $(2011,2013)]$.

This model brings together two important strands of the taxation literature [see the above applications of this model for a detailed list of the references]. On one hand, it follows in the footsteps of computable general equilibrium modeling. It shares with this literature the ability to 
consider the tax system in great detail. On the other hand, it incorporates many of the insights of the endogenous growth literature. In particular, it recognizes that public policies have the potential to affect the fundamentals of long term growth and not just for generating temporary level effects [see Xepapadeas (2005)].

The key distinguishing feature of this model in the applied energy policy literature is its focus on endogenous growth and the associated treatment of public sector optimization behavior (see Conrad 1999; Bergman 2005; for literature surveys). Productivity enhancing public sector investment in public capital and human capital, which have been largely overlooked in applied energy policy (e.g. Carraro et al. 2009), are, in addition to private investment, the drivers of endogenous growth. Our focus is on strategic long-term choices in a policy environment framed by concerns over both growth and fiscal consolidation. This being the case our focus on endogenous growth and on public sector behavior is most appropriate.

The fuel price scenarios are based on forecasts by the US Department of Energy (DOEUS) and the OECD International Energy Agency (IEA-OECD). These forecasts are widely used in policy analysis and macroeconomic forecasting exercises. Indeed, the DOE-US forecasts are commonly used by the US government while the IEA-OECD forecasts are commonly used in the EU. These forecasts correspond to, sometimes dramatically, different scenarios which allow us to examine the impact of differences in relative fossil fuel prices as well as absolute price levels.

The remainder of this paper is organized as follows. Section 2 provides a description of the dynamic general equilibrium model and discusses several implementation issues. Section 3 presents the fuel prices scenarios. Section 4 analyzes the impact of the fossil fuel prices scenarios and section 5 provides sensitivity analyses. Finally, section 6 includes a summary and concluding remarks. 


\section{The Dynamic General Equilibrium Model}

We consider a decentralized economy in a dynamic general-equilibrium framework. All agents are price-takers and have perfect foresight. With money absent, the model is framed in real terms. There are four sectors in the economy - the production sector, the household sector, the public sector and the foreign sector. The first three have an endogenous behavior but all four sectors are interconnected through competitive market equilibrium conditions, as well as the evolution of the stock variables and the relevant shadow prices. All markets are assumed to clear.

The trajectory for the economy is described by the optimal evolution of nine stock and six shadow price variables - private capital, wind energy capital, hydroelectric energy capital, public capital, human capital, and public debt together with their shadow prices, and foreign debt, private financial wealth, and human wealth. In the long term, endogenous growth is determined by the optimal accumulation of private capital, public capital and human capital. The last two are publicly provided.

\subsection{The Production Sector}

Figure 1 presents an overview of the production structure of the economy. Aggregate output, $Y_{t}$, is produced with a Constant Elasticity of Substitution (CES) technology, as in (Eq. 1), linking value added, $V A_{t}$, and aggregate primary energy demand, $A G G_{-} E_{t}$. Value added is produced with a Cobb-Douglas technology (Eq. 2), exhibiting constant returns to scale in the reproducible inputs - effective labor, $L_{t}^{d} H K_{t}$, private capital, $K_{p, t}$, and public capital, $K G_{t}$. Only the demand for labor, $L_{t}^{d}$, and the private capital stock are directly controlled by the firm, meaning that if public investment is absent then decreasing returns set in. Endogenous growth is induced by the presence of constant returns to scale in the factors that accumulate thereby endogenously determining the growth rate of the economy. Public infrastructure and the 
economy-wide stock of knowledge, $H K_{t}$, are publicly financed and are positive externalities. The capital and labor shares are $\theta_{K}$ and $\theta_{L}$, respectively, and $\theta_{K G}=1-\theta_{K}-\theta_{L}$ is a public capital externality parameter. $A$ is a size parameter.

Private capital accumulation is characterized by (Eq. 3) where physical capital depreciates at a rate $\delta_{K}$. Gross investment, $I_{p, t}$, is dynamic in nature with its optimal trajectory induced by the presence of adjustment costs. These costs are modeled as internal to the firm - a loss in capital accumulation due to learning and installation costs - and are meant to reflect rigidities in the accumulation of capital towards its optimal level. Adjustment costs are assumed to be non-negative, monotonically increasing, and strictly convex. In particular, we assume adjustment costs to be quadratic in investment per unit of installed capital.

The firms' net cash flow, $N C F$, (Eq. 4), represents the after-tax position when revenues from sales are netted of wage payments and investment spending. The after-tax net revenues reflect the presence of a private investment, wind energy and hydroelectric energy investment tax credit at an effective rate of $\tau_{I T C}$ and $\tau_{I T C, i}$, respectively, taxes on corporate profits at a rate of $\tau_{C I T}$, and social security contributions paid by the firms on gross salaries, $w_{t} L_{t}^{d} H K_{t}$, at an effective rate of $\tau_{F S S C}$.

Buildings make up a fraction, $0<\left(1-\rho_{I}\right)<1$, of total private investment expenditure. Only this fraction is subject to value-added and other excise taxes, the remainder is exempt. This situation is modeled by assuming that total private investment expenditure is taxed at an effective rate of $\tau_{V A T E T, I}$. The corporate income tax base is calculated as $Y_{t}$ net of total labor costs, $\left(1+\tau_{F S S C}\right) w_{t} L_{t}^{d} H K_{t}$, and net of fiscal depreciation allowances over past and present capital investments, $\alpha I_{t}$, and renewable energy investments, $\alpha I_{i, t}$. A straight-line fiscal depreciation method over NDEP periods is used and investment is assumed to grow at the same rate at which 
output grows. Under these assumptions, depreciation allowances simplify to $\alpha I_{t}$, where $\alpha$ is obtained by computing the difference of two infinite geometric progression sums, and is given by (Eq. 5).

Optimal production behavior consists in choosing the levels of investment and labor that maximize the present value of the firms' net cash flows, (Eq. 4), subject to the equation of motion for private capital accumulation, (Eq. 3). The demands for labor and investment are given by (Eq. 6) and (Eq. 7), respectively, and are obtained from the current-value Hamiltonian function, where $q_{t+1}^{K}$ is the shadow price of private capital, which evolves according to (Eq. 8). Finally, with regard to the financial link of the firm with the rest of the economy, we assume that at the end of each operating period the net cash flow is transferred to the consumers.

\subsection{The Energy Sector}

The energy sector is defined with respect to primary energy demand by firms. Primary energy demand refers to energy that has not undergone any transformation process. We consider demand for crude oil, natural gas, coal, wind energy and hydroelectric energy. Fossil fuels crude oil, natural gas and coal - are imported from the foreign sector. Investment in wind energy and hydroelectric energy infrastructures are undertaken by domestic firms. Expenditure on fossil fuels, (Eq. 10 ), and investment in wind and hydroelectric infrastructures enter directly into the firms' net cash flow. Investment in wind and hydroelectric infrastructure are granted depreciation allowances and corporate income tax deductions.

Aggregate energy demand by firms is produced according to a CES production technology defined with respect to crude oil and other energy inputs, as in (Eq. 9). The distinction at this nest of the production function arises from the fact that oil products are primarily used to in transportation services while natural gas, coal and renewable energies are 
used in electric power generation and industry. As such, the ease with which firms can substitute between crude oil and other energy inputs is limited by the elasticity of substitution in the energy nest of the production technology. In contrast, natural gas, coal and renewable energies are relatively close substitutes in electric power generation and industry. This is reflected in a unitary elasticity of substitution among them in a Cobb Douglas production technology for this nest (Eq. 11). Demand for natural gas and coal are defined to minimize energy system costs and equalize the technical rate of substitution and the price ratio for these two fossil fuel inputs (Eq. 12).

The Portuguese electricity market is in the process of deregulation. The expectation is that the deregulation of production activities will continue and yield competitive market outcomes. In the model the assumption of competitive equilibrium in this market is an approximation consistent with these trends and our long term focus.

Figure 1: Overview of the Production Structure

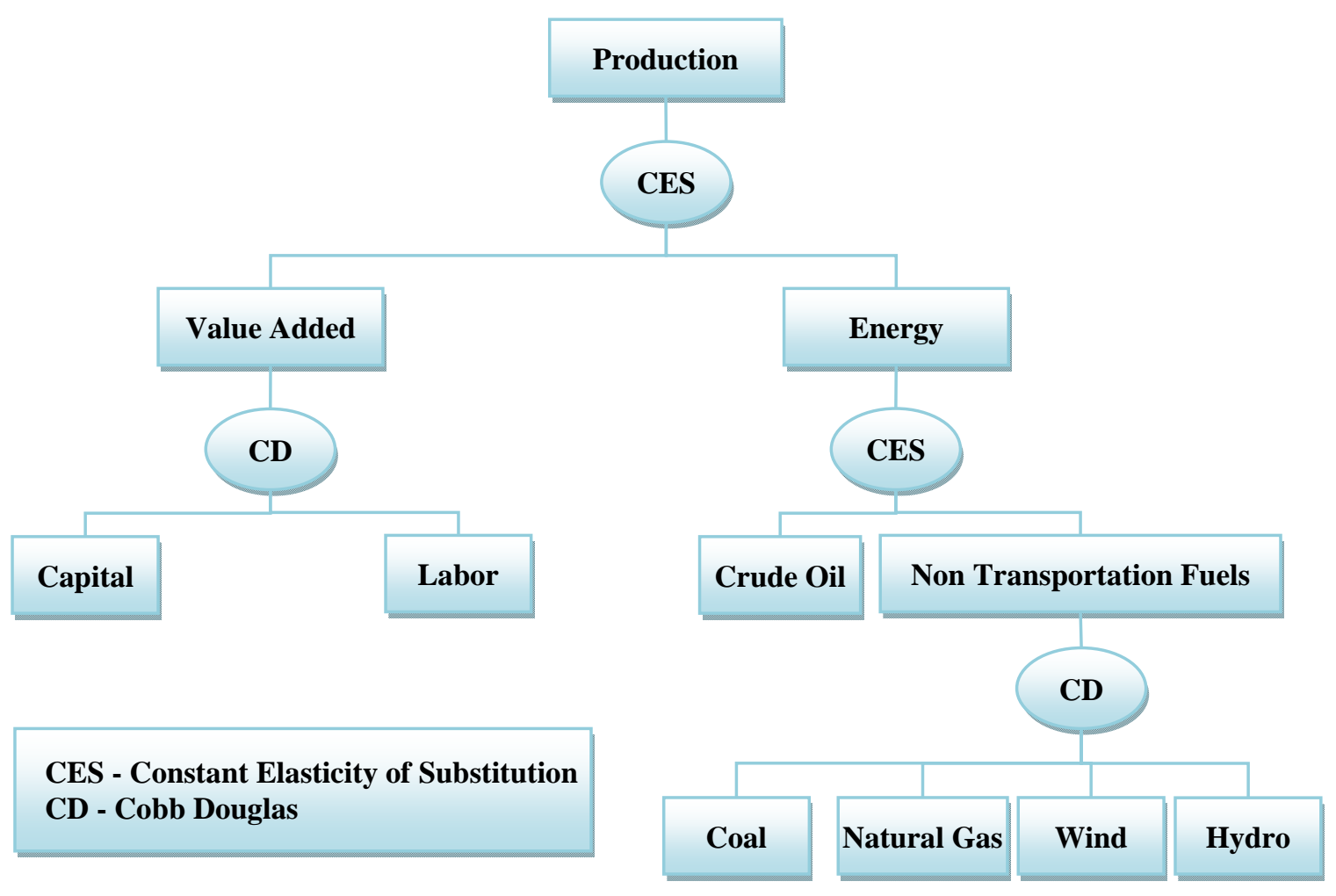


The accumulation of wind and hydroelectric infrastructure are described by (Eq. 15) where the physical capital depreciates at a rate $\delta_{R K, j}$, with $j=$ Wind,Hydro. Gross investment, $I_{j, t}$, is dynamic in nature with its optimal trajectory induced by the presence of adjustment costs. Adjustment costs are internal to the firm and defined analogously to that for private capital. Optimal renewable energy investment levels are defined by differentiating the present valued Hamiltonian with respect to the investment flow and setting equal to zero (Eq. 15). The co-state equation (Eq. 16) is obtained by setting the derivative the Hamiltonian with respect to the capital stock equal to the its shadow price.

Optimal production behavior for energy activities consists in choosing the levels of investment and fossil fuel demand that maximize the present value of the firms' net cash flows, (Eq. 4), subject to the equation of motion for wind and hydroelectric capital accumulation, (Eq. 14). The demands investments are given by (Eq. 15), , and are obtained from the current-value

Hamiltonian function, where $q_{t+1}^{R K, j}$ is the shadow price of each renewable energy capital, which evolves according to (Eq. 16).

\subsection{The Households}

An overlapping-generations specification was adopted in which the planning horizon is finite but in a non-deterministic fashion. A large number of identical agents are faced each period with a probability of survival, $\gamma$. The assumption that $\gamma$ is constant over time and across agecohorts yields a perpetual youth specification in which all agents face a life expectancy of $\frac{1}{1-\gamma}$. Without loss of generality, the population, which is assumed to be constant, is normalized to one. Therefore, per capita and aggregate values are equal. 


\section{The Production Sector}

$$
\begin{aligned}
& Y_{t}=A_{t}\left(\gamma_{v a} V A_{t}^{\rho_{v a}}+\left(1-\gamma_{v a}\right) A G G_{-} E_{t}^{\rho_{v a}}\right)^{1 / \rho_{v a}} \\
& V A_{t}=A_{v a, t}\left(L_{t}^{d} H K_{t}\right)^{\theta_{L}} K_{p, t}^{\theta_{K}} K G_{t}^{1-\theta_{L}-\theta_{K}} \\
& K_{p, t+1}=\left(1-\delta_{k}\right) K_{p, t}+I_{p, t}-\mu_{k} \frac{I_{p, t}^{2}}{K_{p, t}} \\
& N C F_{t}=Y_{t}-\left(1+\tau_{f s s c}\right) w_{t}\left(L_{t}^{d} H K_{t}\right)-I_{p, t}-I_{W, t}-I_{H, t}-\left(1-\rho_{I}\right) \tau_{v a t, I} I_{p, t}-p_{e, t} E_{t} \\
& -\tau_{c i t}\left(Y_{t}-\left(1+\tau_{f s s c}\right) w_{t}\left(L_{t}^{d} H K_{t}\right)-\alpha I_{p, t}-\alpha I_{w, t}-\alpha I_{H, t}-p_{e, t} E_{t}\right)+\tau_{i t, I} I_{p, t}+\tau_{i t c, w} I_{w, t}+\tau_{i t c, H} I_{H, t} \\
& \alpha=\left[1-(1+g)^{-N D E P}\right] / N D E P\left[1-(1+g)^{-1}\right] \\
& \theta_{L} \gamma_{V A} A_{t}\left(\gamma_{v a} V A_{t}^{\rho_{v a}}+\left(1-\gamma_{v a}\right) A G G_{-} E_{t}^{\rho_{v a}}\right)^{1 / \rho_{v a}-1} V A_{t}^{\rho_{V A}}=\left(1+\tau_{F S S C}\right) w_{t} L_{t}^{d} H K_{t} \\
& \frac{I_{p, t}}{K_{p, t}}=\frac{1}{2 \mu_{I}}-\left[1+\left(1-\rho_{I}\right) \tau_{V A T, I}-\alpha \tau_{C I T}-\tau_{I T C, I}\right]\left(2 \mu_{I} q_{t+1}^{K}\right)^{-1}\left(1+r_{t+1}\right) \\
& q_{t}^{K}=\left(1-\tau_{C I T}\right) \theta_{K} \frac{Y_{t}}{K_{p, t}}+\frac{q_{t+1}^{K}}{1+r_{t+1}}\left[1-\delta_{K}+\mu_{I}\left(\frac{I_{p, t}}{K_{p, t}}\right)^{2}\right]
\end{aligned}
$$

\section{The Energy Sector}

$$
\begin{aligned}
& A G G_{-} E_{t}=A_{E, t}\left(\gamma_{E} \text { Crude Oil }{ }_{t}^{\rho_{e}}+\left(1-\gamma_{E}\right) N T F_{t}^{\rho_{e}}\right)^{1 / \rho_{e}} \\
& p_{e, t} E_{t}=\sum_{i=1}^{n} p_{f, i, t} F_{i, t}+p_{\text {crude oil }, t} \text { Crude Oil } \\
& N T F_{t}=A_{E 2, t} \prod_{j=1}^{m}\left(\varphi_{c f, j} R K_{j}\right)_{t}^{\theta_{R K, j}} \prod_{i=1}^{n} F_{i, t}^{\theta_{f, i}} \\
& \frac{\theta_{f, j} F_{i, t}}{\theta_{f, i} F_{j, t}}=\frac{p_{f, j, t}}{p_{f, i, t}} \\
& \frac{A G G_{-} E_{t}}{\text { Crude Oil }}\left(1-\gamma_{V A}\right) A_{t}\left(\gamma_{v a} V A_{t}^{\rho_{v a}}+\left(1-\gamma_{v a}\right) A G G_{-} E_{t}^{\rho_{v a}}\right)^{1 / \rho_{v a}-1} \gamma_{E} A_{E, t}\left(\gamma_{E} \text { Crude Oil } l_{t}^{\rho_{e}}+\left(1-\gamma_{E}\right) N T F_{t}^{\rho_{e}}\right)^{1 / \rho_{e}-1} \text { Crude Oil } l_{t}^{\rho_{e}}=p_{\text {crude oil }, t} \\
& R K_{j, t+1}=\left(1-\delta_{r k, j}\right) R K_{j, t}+I_{j, t}-\mu_{r k, j} \frac{I_{j, t}^{2}}{R K_{j, t}} \\
& \frac{I_{j, t}}{R K_{j, t}}=\frac{1}{2 \mu_{r k, j}}-\left(1+\left(1-\rho_{I}\right) \tau_{v a t, j}-\alpha \tau_{c i t}-\tau_{i t c r, j}\right)\left(2 \mu_{r k, j} q_{t+1}^{R K, j}\right)^{-1}\left(1+r_{t+1}\right) \\
& q_{t}^{R K, j}=\frac{\partial \pi_{t}}{\partial R K_{j, t}}=\left(1-\tau_{c i t}\right) \theta_{R K, j} \frac{Y_{t}}{R K_{j, t}}+\frac{q_{t+1}^{R K, j}}{(1+r)}\left(\left(1-\delta_{r k, j}\right)+\mu_{r k, j}\left(\frac{I_{j, t}}{R K_{j, t}}\right)^{2}\right)
\end{aligned}
$$




$$
\begin{aligned}
& \text { The Household Sector } \\
& U_{a, t}=\frac{\sigma}{\sigma-1} \sum_{v=0}^{\infty} \gamma^{v} \beta^{v}\left[\begin{array}{c}
\frac{\sigma-1}{\sigma} \\
c_{a+v, t+v}
\end{array}+B \ell_{a+v, t+v}^{\frac{\sigma-1}{\sigma}}\right] \\
& \sum_{v=0}^{\infty} \gamma^{v}\left[1+\left(1-\tau_{r}\right) r_{t+v}\right]^{-v}\left(1+\tau_{V A T, C}\right) C_{a+v, t+v}=T W_{a, t} \\
& T W_{a, t} \equiv H W_{a, t}+F W_{a, t}+P V F_{t} \\
& H W_{a, t}=\sum_{m=0}^{\infty}\left(\frac{\gamma}{1+\left(1-\tau_{r}\right) r_{t+m}}\right)^{m}\left(\left(1-\tau_{p i t}\right)\left(\left(1-\tau_{w s s c}\right) w_{t+m}\left(\bar{L}-\ell_{a+m, t+m}\right) H K_{t+m}\right)+T R_{t+m}+R_{t+m}-L S T_{t+m}\right) \\
& F W_{a, t}=\left(1+\left(1-\tau_{r}\right) r_{t-1}^{p d}\right) P D_{t-1}+\left(1-\tau_{\pi}\right) N C F_{t-1}-\left(1+r_{t-1}^{f d}\right) F D_{t-1}+\left(1-\tau_{p i t}\right)\left(\left(1-\tau_{w s s c}\right) w_{t-1}\left(\bar{L}-\ell_{a-1, t-1}\right) H K_{t-1}\right) \\
& \quad+T R_{t-1}+R_{t-1}-L S T_{t-1}-\left(1+\tau_{v a t}\right) C_{a-1, t-1} \\
& \left(1+\tau_{v a t}\right) C_{t}=\left[1-\left(1+\left(1-\tau_{r}\right) r_{t-1}\right)^{\sigma-1} \gamma \beta^{\sigma}\right]\left(H W_{t}+\left(P D_{t}-F D_{t}\right)+P V F_{t}\right) \\
& \ell_{t}=\left(\frac{B\left(1+\tau_{v a t}\right)}{\left(1-\tau_{w s s c}\right)\left(1-\tau_{p i t}\right) w_{t}\left(1-U R_{t}\right) H K_{t}}\right)^{\sigma} C_{t}
\end{aligned}
$$

\section{The Public Sector}

$$
\begin{aligned}
& U_{\text {public }}=\sum_{t}\left[\left(C_{t} \ell_{t}^{p_{1}}\right)^{\alpha_{C}} C G_{t}^{1-\alpha_{C}}\right]\left(1+\left(1-\tau_{r}\right) r_{t}^{P D}\right)^{-t} \\
& P D_{t+1}=\left(1+r_{t}^{P D}\right) P D_{t}+\left(1+\tau_{v a t, c g}\right) C G_{t}+\left(1+\tau_{v a t, i g}\right) I G_{t}+\left(1+\tau_{v a t, i h}\right) I H_{t}+T R_{t}-T_{t} \\
& T_{t}=P I T_{t}+C I T_{t}+V A T_{t}+F S S C_{t}+W S S C_{t}+L S T_{t} \\
& K G_{t+1}=\left(1-\delta_{k g}\right) K G_{t}+I G_{t}-\mu_{k g} \frac{I G_{t}^{2}}{K G_{t}} \\
& H K_{t+1}=\left(1-\delta_{h k}\right) H K_{t}+I H_{t}-\mu_{h k} \frac{I H_{t}^{2}}{H K_{t}} \\
& \frac{q_{t+1}^{P D}}{\left(1+\left(1-\tau_{r}\right) r_{t+1}^{P D}\right)}=\frac{q_{t}^{P D}}{\left(1+\left(1-\tau_{r}\right) r_{t}^{P D}\right)} \\
& q_{t+1}^{P D}=\left(1-\alpha_{c}\right)\left(\frac{C_{t} \ell^{p_{1}}}{C G_{t}}\right)^{\alpha_{C}}\left(1+\left(1-\tau_{r}\right) r_{t}^{P D}\right) \\
& -q_{t+1}^{P D}=q_{t+1}^{k g}\left(1-2 \mu_{k g} \frac{I G_{t}}{K G_{t}}\right) \\
& q_{t}^{K G}=\frac{q_{t+1}^{P D}}{\left(1+\left(1-\tau_{r}\right) r_{t+1}^{P D}\right)}\left(\left(\tau_{\pi}\left(1-\tau_{c i t}\right)+\tau_{c i t}\right) \frac{\partial Y_{t}}{\partial K G_{t}}\right)+\frac{q_{t+1}^{k g}}{\left(1+\left(1-\tau_{r}\right) r_{t+1}^{P D}\right)}\left(\left(1-\delta_{k g}\right)+\mu_{k g}\left(\frac{I G_{t}}{K G_{t}}\right)^{2}\right) \\
& -q_{t+1}^{P D}=q_{t+1}^{h k}\left(1-\mu_{h k} \frac{I H_{t}}{H K_{t}}\right) \\
& q_{t}^{H K}=\frac{q_{t+1}^{P D}}{\left(1+\left(1-\tau_{r}\right) r_{t}^{P D}\right)}\left(\left(\tau_{p i t}\left(1-\tau_{f s s c}\right)-\left(1-\tau_{\pi}\right)\left(1+\tau_{c i t}\right) \tau_{f s s c}+\tau_{w s s c}\right) \frac{\partial Y_{t}}{\partial H K_{t}}\right) \\
& \quad \frac{q_{t+1}^{h k}}{\left(1+\left(1-\tau_{r}\right) r_{t+1}^{P D}\right)}\left(\left(1-\delta_{h k}\right)+\mu_{h k}\left(\frac{I H_{t}}{H K_{t}}\right)^{2}\right)
\end{aligned}
$$

\section{Market Equilibrium}

$\left(1-U R_{t}\right) L S_{t}=L_{t}^{d}$

$Y_{t}=\sum_{i=1}^{n} p_{f, i, t} F_{i, t}+p_{\text {crude oil }, t}$ Crude Oil ${ }_{t}+C_{t}+I_{p, t}+\sum_{\mathrm{J}} I_{j, t}+C G_{t}+I G_{t}+I H_{t}-N X_{t}$

$F D_{t+1}=\left(1+r_{t}^{f d}\right) F D_{t}+N X_{t}-R_{t}$

$F W_{t}=P D_{t}-F D_{t}$ 
The household, aged $a$ at time $t$, chooses consumption and leisure streams that maximize intertemporal utility, (Eq. 17), subject to the consolidated budget constraint, (Eq. 18). The objective function is lifetime expected utility subjectively discounted at the rate of $\beta$. Preferences, $u_{a+v, t+v}$, are additively separable in consumption and leisure, and take on the CES form where $B$ is a size parameter and $\sigma$ is the constant elasticity of substitution. The effective subjective discount factor is $\gamma \beta$ meaning that a lower probability of survival reduces the effective discount factor making the household relatively more impatient.

The budget constraint, (Eq. 18), reflects the fact that consumption is subject to a valueadded tax rate of $\tau_{V A T, C}$ and states that the households' expenditure stream discounted at the after-tax market real interest rate, $1+\left(1-\tau_{r}\right) r_{t+v}$, cannot exceed total wealth at $t, T W_{a, t}$. The loan rate at which households borrow and lend among themselves is $1 / \gamma$ times greater than the after-tax interest rate reflecting the probability of survival.

For the household of age $a$ at $t$, total wealth, $T W_{a, t}$ (Eq. 19), is age-specific and is composed of human wealth, $H W_{a, t}$, net financial worth, $F W_{a, t}$, and the present value of the firm, $P V F_{t}$. Human wealth (Eq. 20), represents the present discounted value of the household's future labor income stream net of personal income taxes, $\tau_{P I T}$, and workers' social security contributions, $\tau_{W S S C}$. Labor's reward per efficiency unit is $w_{t}$.

The household's wage income is determined by its endogenous decision of how much labor to supply, $L S_{t}=\bar{L}-\ell_{t}$, out of a total time endowment of $\bar{L}$, and by the stock of knowledge or human capital, $H K_{t}$, which is financed by public investment on education. Labor earnings are discounted at a higher rate reflecting the probability of survival.

The availability of educational opportunities is largely determined by the public sector, which finances the bulk of elementary and secondary education and most of the higher 
education, that is, education is mostly a publicly-provided good. This approach to human capital is natural at our very aggregate level and adequate for our long term analysis. The component of time affected to schooling is exogenous and fixed at the observed historical levels. The remaining time is optimally chosen between leisure and labor participation which is consistent with our interest in measuring the labor market effects.

A household's income is augmented by net interest payments received on public debt, $P D_{t}$, profits distributed by corporations, $N C F_{t}$, international transfers, $R_{t}$, and public transfers, $T R_{t}$. On the spending side, debts to foreigners are serviced, taxes are paid and consumption expenditures are made. Income net of spending adds to net financial wealth (Eq. 21). Under the assumption of no bequests, households are born without any financial wealth. In general, total wealth is age-specific due to age-specific labor supplies and consumption streams.

Assuming a constant real interest rate, the marginal propensity to consume out of total wealth is age-independent and aggregation over age cohorts is greatly simplified. Aggregate consumption demand is given by (Eq. 22) and an age-independent coefficient enables us to write the aggregate demand for leisure, (Eq. 23), as a function of aggregate consumption.

\subsection{The Public Sector}

The equation of motion for public debt, $P D_{t}$, (Eq. 25), reflects the fact that the excess of government expenditures over tax revenues has to be financed by increases in public indebtedness. Total tax revenues, $T_{t}$, (Eq. 26) include personal income taxes, $P I T_{t}$, corporate income taxes, $C I T_{t}$, value added taxes, $V A T_{t}$, social security taxes levied on firms and workers $F_{S S T}$ and $W_{S S T}$. All of these taxes are levied on endogenously defined tax bases. Residual taxes are modeled as lump sum, $L S T_{t}$, and are assumed to grow at an exogenous rate. 
The public sector pays interest on public debt at a rate of $r_{t}^{P D}$ and transfers funds to households, $T R_{t}$, in the form of pensions, unemployment subsidies, and social transfers, which grow at an exogenous rate. Our exogenous interest rate specification is due to our focus on steady state effects. Thus, we are interested in structural features of the economy and consider a baseline public debt to GDP ratio within acceptable ranges for debt that would not suggest a significant idiosyncratic associated risk premium. The public sector engages in public consumption activities, $C G_{t}$, and public investment in both public capital and human capital, $I G_{t}$ and $I H_{t}$.

Figure 2: Overview of the Public Sector

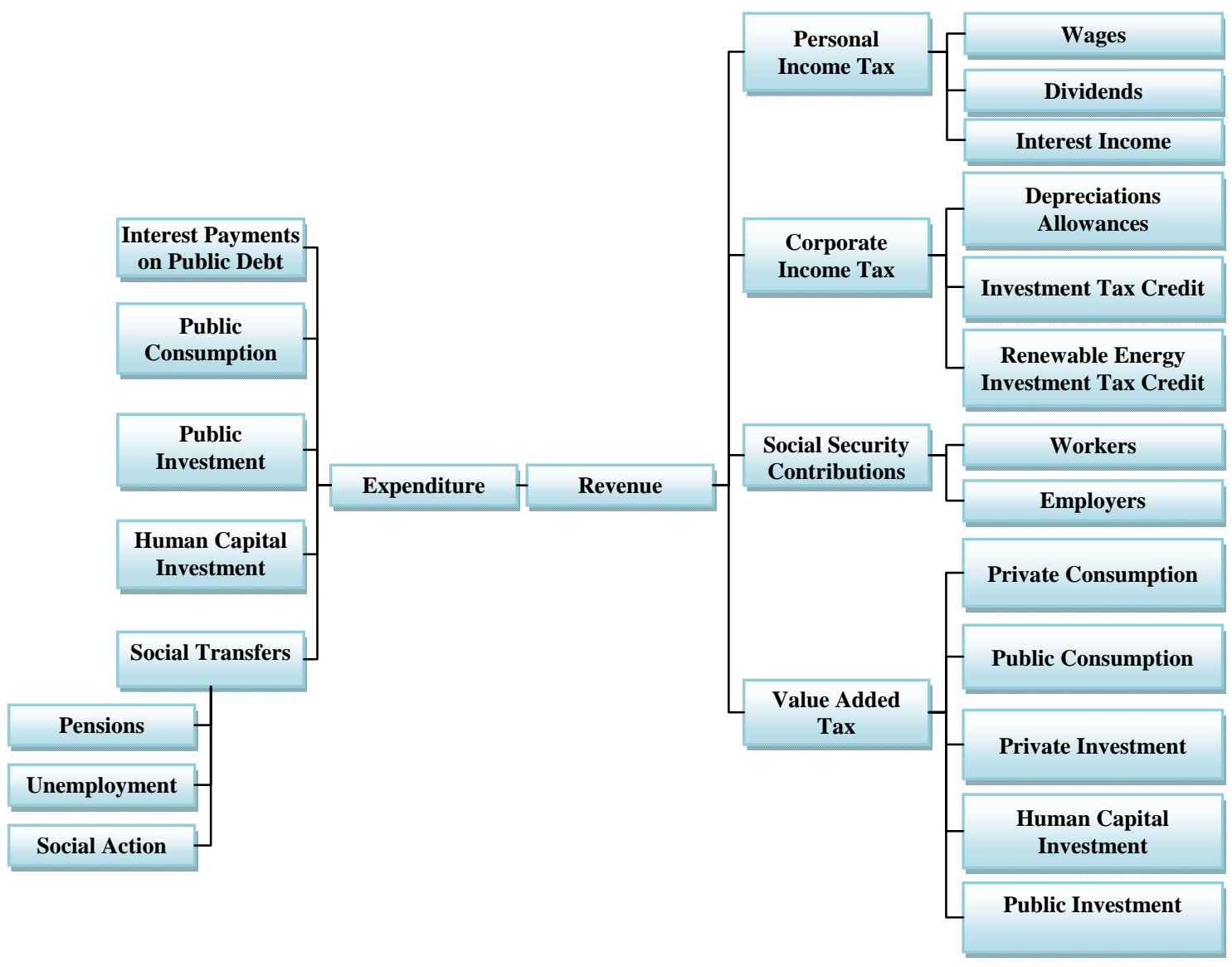


Public investments are determined optimally, respond to economic incentives, and constitute an engine of endogenous growth. The accumulations of $H K_{t}$ and $K G_{t}$ are subject to depreciation rates, $\delta_{H K}$ and $\delta_{H K}$, and to adjustment costs that are a fraction of the respective investment levels. The adjustment cost functions are strictly convex and quadratic.

Public sector decisions consist in choosing the trajectories for $C G_{t}, I H_{t}$, and $I G_{t}$ that maximize social welfare, (Eq. 24), defined as the net present value of the future stream of utility derived from public consumption, parametric on private sector consumption-leisure decisions. The optimal choice is subject to three constraints, the equations of motion of the stock of public debt, (Eq. 25), the stock of public capital, (Eq. 27), and the stock of human capital, (Eq. 28).

The optimal trajectories depend on $q_{t+1}^{P D}, q_{t+1}^{K G}$, and $q_{t+1}^{H K}$, the shadow prices of the public debt, public capital, and human capital stocks, respectively. The relevant discount rate is $1+\left(1-\tau_{r}\right) r_{t+1}^{P D}$ because this is the financing rate for the public sector. Optimal conditions are (Eq. 29) for public debt, (Eq. 30) for public consumption, (Eq. 31-34) for public investment, and (Eq. 35-36) for investment in human capital.

\subsection{Social Welfare}

Social welfare consists of both a private and a public component. The private component of social welfare is defined in an infinite horizon context as a function of private consumption and leisure, as is typical in the literature. We extend this general framework to account for the fact that public consumption activities affect social welfare. The private and public components of social welfare are combined in a fashion consistent with the shares of private and public consumption in total consumption. These social welfare assessments are conservative in that they do not explicitly account for the environmental benefits associated with a reduction in $\mathrm{CO}_{2}$ emissions from fossil fuel combustion, nor the correlated benefits in air quality improvement. 
Table 2: The Dynamic General Equilibrium Model - The Basic Data Set

\begin{tabular}{|c|c|c|}
\hline \multicolumn{3}{|l|}{ Domestic spending data ( percent of $Y_{0}$ ) } \\
\hline$Y_{0}$ & GDP (billion Euros) & 166.228 \\
\hline$g_{0}$ & Long term growth rate ( percent) & 1.763 \\
\hline$V A_{0}$ & Value added & 85.393 \\
\hline$A G G_{-} E_{0}$ & Primary energy consumption expenditure & 2.557 \\
\hline$C_{0}$ & Private consumption & 62.343 \\
\hline$I_{p, 0}$ & Private investment & 20.223 \\
\hline$I_{w, 0}$ & Private wind investment & 0.064 \\
\hline$I_{H, 0}$ & Private hydro investment & 0.089 \\
\hline$C G_{0}$ & Public consumption & 12.285 \\
\hline$I G_{0}$ & Public capital investment & 3.329 \\
\hline$I H_{0}$ & Public investment in education & 7.025 \\
\hline \multicolumn{3}{|c|}{ Primary energy demand (GJ as a percent of $Y_{0}$ ) } \\
\hline$E_{0}$ & Primary fossil energy spending & 2.472 \\
\hline$N T F_{0}$ & Non transportation fuels & 0.701 \\
\hline$F E_{0}$ & Fossil fuels (excluding crude oil) & 0.160 \\
\hline CrudeOil $_{0}$ & Quantity of crude oil imports & 0.321 \\
\hline$F_{\text {Coal }, 0}$ & Quantity of coal imports & 0.082 \\
\hline$F_{\text {Natural Gas, } 0}$ & Quantity natural gas imports & 0.077 \\
\hline \multicolumn{3}{|l|}{ Energy prices (€ per GJ) } \\
\hline$p_{\text {Crude oil }, 0}$ & Import price of crude oil & 6.140 \\
\hline$p_{f, \text { Coal }, 0}$ & Import price of coal & 1.890 \\
\hline$p_{f, N a t u r a l \text { Gas }, 0}$ & Import price of natural gas & 4.450 \\
\hline \multicolumn{3}{|l|}{ Foreign account data ( percent of $Y_{0}$ ) } \\
\hline$N X_{0}$ & Trade deficit & 5.358 \\
\hline$r_{0}^{F D} F D_{0}$ & Interest payments of foreign debt & 2.933 \\
\hline$R_{0}$ & Unilateral transfers & 8.855 \\
\hline$C A D_{0}$ & Current account deficit & 1.908 \\
\hline$F D_{0}$ & Foreign debt & 108.200 \\
\hline \multicolumn{3}{|l|}{ Public sector data ( percent of $Y_{0}$ ) } \\
\hline$T_{0}$ & Total tax revenue & 39.366 \\
\hline$P I T_{0}$ & Personal income tax revenue & 5.392 \\
\hline$C I T_{0}$ & Corporate income tax revenue & 3.094 \\
\hline$V A T_{0}$ & Value added tax revenue & 12.050 \\
\hline$V A T_{c}$ & on private consumption expenditure & 9.351 \\
\hline$V A T_{I}$ & on private investment expenditure & 1.739 \\
\hline$V A T_{c g}$ & on public consumption expenditure & 0.521 \\
\hline$V A T_{i g}$ & on public capital investment expenditure & 0.333 \\
\hline$V A T_{i h}$ & on public investment in human capital & 0.100 \\
\hline$W_{S S C}$ & Social security tax revenues & 11.700 \\
\hline$W S S C_{1,0}$ & employers contributions & 5.600 \\
\hline$W_{S S C} C_{2,0}$ & workers contributions & 6.100 \\
\hline Carbon $\operatorname{Tax}_{0}$ & Carbon tax & 0.000 \\
\hline$L S T_{0}$ & Lump sum tax revenue & 7.130 \\
\hline$T R_{t}$ & Social transfers & 15.915 \\
\hline$r_{0}^{P D} P D_{0}$ & Interest payments of public debt & 2.326 \\
\hline$D E F_{0}$ & Public deficit & 1.513 \\
\hline$P D_{0}$ & Public debt & 85.800 \\
\hline
\end{tabular}


Table 2 (con't): The Dynamic General Equilibrium Model - The Basic Data Set

\begin{tabular}{clr}
\hline \hline Population and employment data ( Millions) & & \\
$P O P_{0}$ & Population (in thousands) & 10.608 \\
$L_{0}$ & Active population & 5.614 \\
$U R_{0}$ & Unemployment rate & 5.979 \\
\hline Private Wealth (percent of $\boldsymbol{Y}_{\mathbf{0}}$ ) & & \\
$H W_{0}$ & Human wealth & 2827.507 \\
$F W_{0}$ & Financial wealth & -22.400 \\
$P V F_{0}$ & Present value of the firm & 1695.452 \\
$N C F_{0}$ & Distributed profits & 17.603 \\
\hline & & \\
$w_{0}$ & Wage rate & 0.034 \\
$q_{0}^{P D}$ & Shadow price of public debt \\
$q_{0}^{k}$ & Shadow price of private capital & -0.969 \\
$q_{0}^{r k}$ & Shadow price of wind energy capital & 1.288 \\
$q_{0}^{r k}$ & Shadow price of hydro energy capital & 1.288 \\
$q_{0}^{k g}$ & Shadow price of public capital & 1.288 \\
$q_{0}^{h k}$ & Shadow price of human capital & 1.210 \\
& & 8.443 \\
\hline Capital stocks $\left(\right.$ percent of $\left.\boldsymbol{Y}_{\mathbf{0}}\right)$ & Private capital & \\
$K_{0}$ & Wind energy capital stock & 278.134 \\
$R K_{0}$ & Hydro energy capital stock & 1.381 \\
$R K_{0}$ & Public capital stock & 1.838 \\
$K G_{0}$ & Human capital stock & 95.570 \\
$H K_{0}$ & & 218.721 \\
\hline \hline
\end{tabular}

\subsection{The Foreign Sector}

The equation of motion for foreign financing, $F D_{t}$, (Eq. 37), provides a stylized description of the balance of payments. Domestic production, $Y_{t}$, and imports are absorbed by domestic expenditure and exports. Net imports, $-N X_{t}$, (Eq. 36), are financed through foreign transfers, $R_{t}$, and foreign borrowing. Foreign transfers grow at an exogenous rate. In turn, the domestic economy is assumed to be a small, open economy. This means that it can obtain the desired level of foreign financing at a rate, $r_{t}^{F D}$, which is determined in the international financial markets. This is the prevailing rate for all domestic agents.

\subsection{The Intertemporal Market Equilibrium}

The intertemporal path for the economy is described by the behavioral equations, by the equations of motion of the stock and shadow price variables, and by the market equilibrium 
conditions (Eq. 35-38). The labor-market clearing condition is given by (Eq. 35) where a structural unemployment rate of $U R_{t}$ is exogenously defined. The product market equalizes demand and supply for goods and services. Given the open nature of the economy, part of the demand is satisfied through the recourse to foreign production, hence (Eq. 36) and (Eq. 37). Finally, the financial market equilibrium, (Eq. 38), reflects the fact that private capital formation and public indebtedness are financed by household savings and foreign financing.

We define the steady-state growth path as an intertemporal equilibrium trajectory in which all the flow and stock variables grow at the same rate $g$ while market prices and shadow prices are constant. There are three types of restrictions imposed by the existence of a steadystate. First, it determines the value of critical production parameters, like adjustment costs and depreciation rates given the initial capital stocks. These stocks, in turn, are determined by assuming that the observed levels of investment of the respective type are such that the ratios of capital to GDP do not change in the steady state. Second, the need for constant public debt and foreign debt to GDP ratios implies that the steady-state public account deficit and the current account deficit are a fraction $g$ of the respective stocks of debt. Finally, the exogenous variables, such as public transfers or international transfers, have to grow at the steady-state growth rate.

\subsection{Dataset, Parameter Specification, and Calibration}

The model is implemented numerically using detailed data and parameters sets reported in Table 3. The dataset reflects the GDP and stock variable values in 2008; public debt and foreign debt reflect the most recent available data. Data are from the Statistical Annex of the European Community (2012), the Portuguese Ministry of Finance (2012) and the Portuguese Directorate General for Geology and Energy (2012). The decomposition of the macroeconomic variables follows the average for the period 1990-2008 for macroeconomic data. This period was 
chosen to reflect the most recent available information and to cover several business cycles, thereby reflecting the long-term nature of the model.

Primary energy demand shows strong annual variations due primarily to hydrological cycles. These tend to produce countervailing balances between hydroelectric and fossil primarily coal and natural gas - energy resources. This variability, coupled with the long term nature of the model, suggests that averages for the respective shares and expenditure levels taken over several years can mitigate any peculiarities associated with calibrating the model data to a single year.

The past ten years, however, has seen very substantial changes to the energy sector. Natural gas has become a dominant fixture in the energy system in Portugal since its introduction in 1997. Similarly, since 2005, installed wind energy capacity has grown exponentially. As a result, we consider the average values between 1999 and 2008 in defining expenditure shares for fossil fuel imports. During this time, imported fossil fuels were valued at an average of to 2.472 percent of GDP. Due to the relatively more recent investment efforts in wind energy, we consider average investment volumes between 2005 and 2010. Wind energy investment volumes are from Energias de Portugal. Hydroelectric infrastructure investment data are from the Portuguese Directorate General for Geology and Energy information regarding installed capacity. The annual change in capacity is used to define investment based on capital cost and fixed operating and maintenance cost data from the U.S. Department of Energy.

Parameter values are specified in different ways. Whenever possible, parameter values are taken from the available data sources or the literature. This is the case, for example, of the population growth rate, the probability of survival, the share of private consumption in private 


\section{Table 3: The Dynamic General Equilibrium Model - The Structural Parameters}

\begin{tabular}{|c|c|c|}
\hline \multicolumn{3}{|l|}{ Household parameters } \\
\hline$\beta$ & Discount rate & 0.001 \\
\hline$\gamma$ & Probability of survival & 0.987 \\
\hline$g_{P O P}$ & Population growth rate & 0.000 \\
\hline$\sigma$ & Elasticity of substitution & 1.000 \\
\hline$p_{1}$ & Leisure share parameter & 0.358 \\
\hline \multicolumn{3}{|l|}{ Production parameters } \\
\hline$\theta_{L}$ & Labor share in value added aggregate & 0.520 \\
\hline$\theta_{K P}$ & Capital share in value added aggregate & 0.290 \\
\hline$\theta_{K G}$ & Public capital share in value added aggregate & 0.190 \\
\hline$\sigma_{V A}$ & Elasticity of substitution between value added and energy & 0.400 \\
\hline$\sigma_{\text {Crude }}$ & Elasticity of substitution between oil and other energy & 0.400 \\
\hline$\theta_{K R}$ & wind energy share in non-transportation fuels & 0.121 \\
\hline$\theta_{K R}$ & wind energy share in non-transportation fuels & 0.167 \\
\hline$\theta_{E}$ & fossil energy share in non-transportation fuels & 0.711 \\
\hline$\varphi_{c f}$ & Wind energy price:quantity capacity utilization factor & 0.146 \\
\hline$\varphi_{c f}$ & Hydro energy price:quantity capacity utilization factor & 0.110 \\
\hline$\theta_{\text {Coal }}$ & coal share in non-transportation fuels & 0.313 \\
\hline$\theta_{\text {gas }}$ & natural gas share in non-transportation fuels & 0.687 \\
\hline$\gamma_{V A}$ & CES scaling share between value added and energy & 1.000 \\
\hline$\gamma_{E}$ & CES scaling share between oil and other energy & 0.466 \\
\hline$\delta_{k}$ & Depreciation rate - Private capital & 0.042 \\
\hline$\mu_{k}$ & Adjustment costs coefficient - Private capital & 1.504 \\
\hline$\delta_{R k}$ & Depreciation rate - Wind energy capital & 0.020 \\
\hline$\mu_{R k}$ & Adjustment costs coefficient - Wind energy capital & 2.360 \\
\hline$\delta_{R k}$ & Depreciation rate - Wind energy capital & 0.022 \\
\hline$\mu_{R k}$ & Adjustment costs coefficient - Wind energy capital & 2.254 \\
\hline$\dot{A}_{i} / A_{i}$ & Exogenous rate of technological progress & 0.000 \\
\hline \multicolumn{3}{|c|}{ Public sector parameters - tax parameters } \\
\hline$\tau_{\text {pit }}$ & Effective personal income tax rate & 0.091 \\
\hline$\tau_{\pi}$ & Effective personal income tax rate on distributed profits & 0.112 \\
\hline$\tau_{r}$ & Effective personal income tax rate on interest income & 0.200 \\
\hline$\tau_{c i t}$ & Effective corporate income tax rate & 0.116 \\
\hline NDEP & Time for fiscal depreciation of investment & 16.000 \\
\hline$\alpha$ & Depreciation allowances for tax purposes & 0.735 \\
\hline$\rho_{I}$ & Fraction of private investment that is tax exempt & 0.680 \\
\hline$\tau_{i t c, I}$ & Investment tax credit rate - Private capital & 0.005 \\
\hline$\tau_{i t c, R I}$ & Investment tax credit rate - Wind energy capital & 0.005 \\
\hline$\tau_{i t c, R I}$ & Investment tax credit rate - Hydro energy capital & 0.005 \\
\hline$\tau_{V A T, C}$ & Value added tax rate on consumption & 0.176 \\
\hline$\tau_{v a t, I}$ & Value added tax rate on investment & 0.094 \\
\hline$\tau_{\text {vat }, c g}$ & Value added tax rate on public consumption & 0.044 \\
\hline$\tau_{v a t, i g}$ & Value added tax rate on public capital investment & 0.111 \\
\hline$\tau_{v a t, i h}$ & Value added tax rate for public investment in human capital & 0.014 \\
\hline$\tau_{f s s c}$ & Firms' social security contribution rate & 0.145 \\
\hline$\tau_{w s s c}$ & Workers social security contribution rate & 0.157 \\
\hline
\end{tabular}


Table 3 (con't): The Dynamic General Equilibrium Model - The Structural Parameters

\begin{tabular}{clr}
\hline \hline Public sector parameters - outlays parameters & & \\
$1-\alpha_{C}$ & Public consumption share & 0.182 \\
$\delta_{k g}$ & Public infrastructure depreciation rate & 0.011 \\
$\mu_{k g}$ & Adjustment cost coefficient & 3.190 \\
$\delta_{h k}$ & Human capital depreciation rate & 0.000 \\
$\mu_{h k}$ & Adjustment cost coefficient & 13.980 \\
\hline Real interest rates & & \\
$r, r^{F D}, r^{P D}$ & Interest rate & 2.711 \\
\hline \hline
\end{tabular}

spending, and the different effective tax rates. All the other parameters are obtained by calibration; i.e., in a way that the trends of the economy for the period 1990-2008 are extrapolated as the steady-state trajectory. These calibration parameters assume two different roles. In some cases, they are chosen freely in that they are not implied by the state-state restrictions. Although free, these parameters have to be carefully chosen since their values affect the value of the remaining calibration parameters. Accordingly, they were chosen either using central values or using available data as guidance. For instance, the elasticity of substitution parameters are consistent with those values often applied in climate policy analysis [see, for example, Manne and Richels (1992), Paltsev et al. (2005) and Koetse et al. (2008)]. The remaining calibration parameters are obtained using the steady-state restrictions.

\section{On the Fuel Price Scenarios}

The fuel price scenarios for the period 2008 to 2035 are based on forecasts developed by the US Department of Energy, (DOE-US) and the International Energy Agency (IEA-OECD) as presented in the Annual Energy Outlook of the US Department of Energy (2010). After 2035, we assume that prices grow at the average growth rate for the last ten years of the forecast. Table 4 
presents the forecasts including a composite energy price index and relative price ratios and Figure 3 presents the forecasts for each of the two fuel price scenarios.

The price scenarios present a range of different level and relative price movements by 2050, including changes in oil prices of 47.8 percent and 32.5 percent, in coal prices of 3.8 percent and -5.3 percent, and in natural gas prices of 11.3 percent and 52.9 percent, in the DOEUS and IEA-OECD scenarios, respectively. Naturally, oil prices tend to dominate the reference fuel price index, relative to coal and natural gas prices, because the demand for oil accounts for more than 65 percent of primary energy demand and for close to 80 percent of the value of imported energy. Overall, the reference fossil fuel price index is projected to grow by 34.4 percent in the DOE-US scenario and by 29.3 percent in the IEA-OECD scenario by 2050.

Table 4: Fuel Price Scenarios

\begin{tabular}{lcrrrr}
\hline \hline & & & & & $(2008=100.00)$ \\
& $\mathbf{2 0 1 0}$ & $\mathbf{2 0 2 0}$ & $\mathbf{2 0 3 0}$ & $\mathbf{2 0 4 0}$ & $\mathbf{2 0 5 0}$ \\
\hline & DOE-US & & & & \\
Reference Fossil Price Index & 97.89 & 102.11 & 114.67 & 128.06 & 134.42 \\
$\quad$ Petroleum and its Products & 98.55 & 108.75 & 124.03 & 140.08 & 147.81 \\
$\quad$ Coal & 99.42 & 96.72 & 98.90 & 102.70 & 103.80 \\
$\quad$ Natural Gas & 93.52 & 80.18 & 92.49 & 105.11 & 111.33 \\
Coal/Natural Gas Ratio & 106.31 & 120.63 & 106.93 & 97.71 & 93.23 \\
Oil/Natural Gas Ratio & 99.12 & 112.43 & 125.41 & 136.40 & 142.40 \\
\hline & IEA-OECD & & & & \\
& 96.79 & 102.36 & 116.40 & 122.17 & 129.27 \\
Reference Fossil Price Index & 96.91 & 102.89 & 118.32 & 124.67 & 132.48 \\
$\quad$ Petroleum and its Products & 93.00 & 86.38 & 90.72 & 92.51 & 94.70 \\
$\quad$ Coal & 100.39 & 117.25 & 135.85 & 143.50 & 152.91 \\
$\quad$ Natural Gas & 92.64 & 73.67 & 66.78 & 64.46 & 61.93 \\
Coal/Natural Gas Ratio & 104.20 & 119.12 & 130.43 & 134.77 & 139.88 \\
Oil/Natural Gas Ratio & & & & & \\
\hline \hline
\end{tabular}


Figure 3 Fossil Fuel Price Scenarios

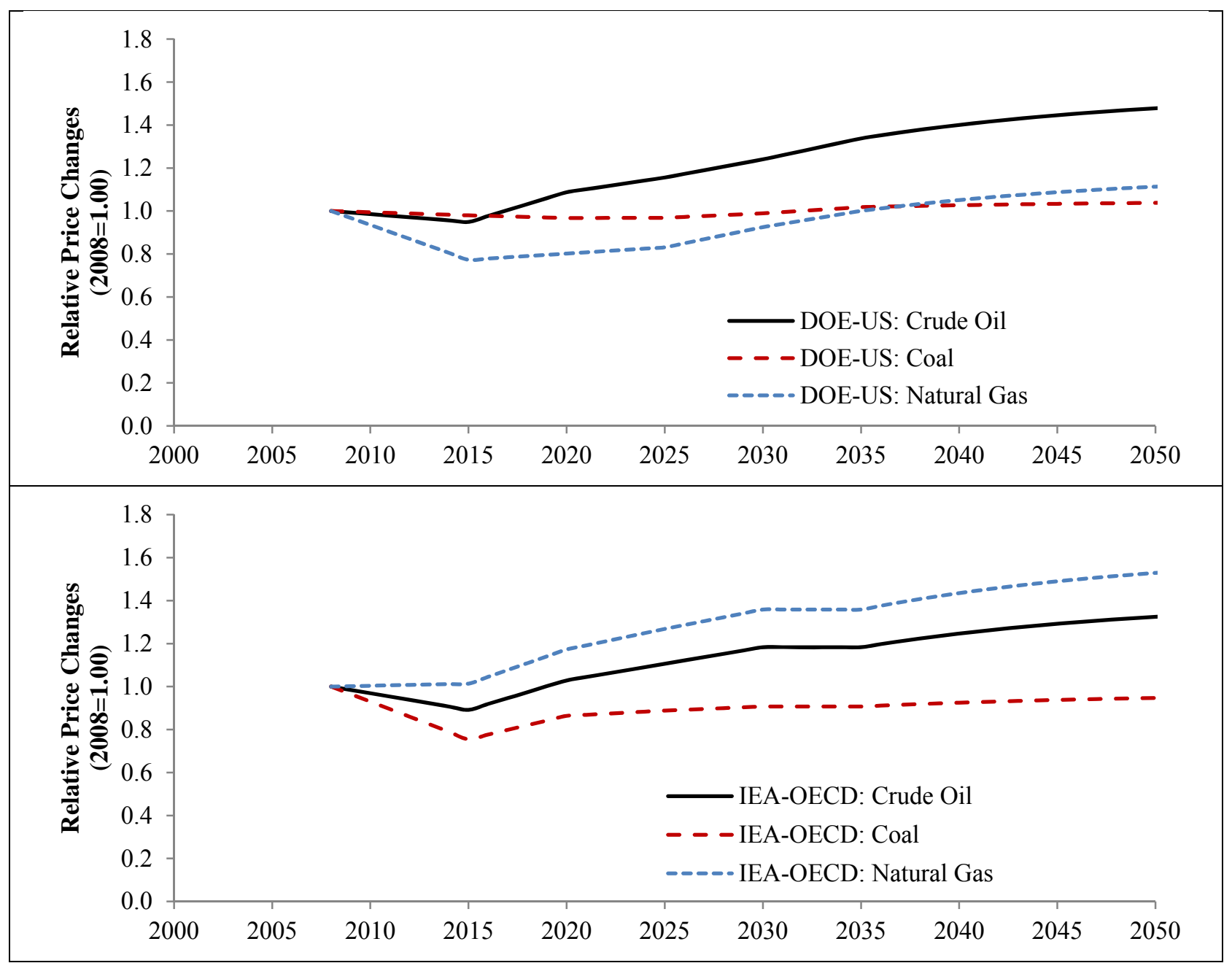

In the shorter term we have even more interesting differences. While the change in the composite price index by 2020 is similar for both the DOE-US and IEA-OECD scenarios, these scenarios differ markedly for coal and natural gas prices, with coal prices growing by 20.6 percent relative to natural gas prices in the DOE-US scenario and falling by 26.3 percent relative to natural gas prices in the IEA-OECD scenario. In addition, crude oil prices fall by more in the IEA-OECD scenario and remain lower throughout the forecast horizon. The two forecasts show a very different intertemporal trajectory for coal and natural gas prices. Natural gas prices grow by more than any other fuel in the IEA-OECD forecast while the DOE-US forecast depicts an 
initial decline and subsequent increase in the price of natural gas, returning to 2008 levels by 2035. Coal prices, on the other hand, show a meaningful drop in price in the IEA-OECD scenario, while remaining relatively stable in the DOE-US scenario. The similarities in the changes to the price index coupled with the substantial differences for individual fuel vectors allow us to highlight both the influence of relative and absolute price changes in a meaningful fashion.

\section{The Impact of Fossil Fuel Prices}

The impacts of the price scenarios are presented in Tables A1-A4 in the appendix and summarized in Figures 4, 5 and 6. In the discussion below, unless indicated otherwise, all figures are percent deviations from the steady state baseline.

\subsection{The Impact on Energy Demand}

Differences in relative prices between the two scenarios are particularly pronounced early in the model horizon. While by 2020 the actual fossil fuel price index based on forecasted demand patterns increases by 2.0 percent in the DOE-US and 2.2 percent in the IEA-OECD scenarios, we observe a 0.2 percent reduction in fossil fuel demand in the DOE-US scenario and a 1.0 percent increase in the IEA-OECD scenario. This is due to the larger drop in fuel prices earlier in the model horizon in the IEA-OECD price scenario. By 2050, however, primary demand for fossil fuels falls in both the DOE-US and IEA-OECD scenarios, by 12.4 percent and 9.5 percent in the DOE-US and in the IEA-OECD scenarios, respectively.

The differences with respect to the aggregate impact on primary energy demand underscore important differences in the composition of energy demand. In the DOE-US scenario we observe an increase in natural gas consumption of 15.5 percent by 2020 . This is the result of 
the 19.8 percent drop in the price of natural gas by 2020 together with the larger array of substitution possibilities for natural gas in industry and electric power. Indeed, the uptake in natural gas demand drives, in part, a 4.4 percent reduction in coal demand and a 9.4 percent reduction in wind energy investment in 2010 and a 3.8 percent reduction in 2020 , driving an accumulated reduction of 2.6 percent in the stock of wind energy infrastructure by 2020 . A similar pattern is observed for hydroelectric energy infrastructures. Over the long term, the persistently high fossil fuel prices yield a 1.0 percent increase in the stock of renewable energy capital relative to steady state levels for both wind and hydroelectric energy infrastructures. The demand for crude oil falls by 2.9 percent in 2020. In this scenario, we clearly observe a shift in the energy mix towards natural gas over the short run and a shift to renewable energies and coal over the long run.

The IEA-OECD scenario considers, on one hand, substantially lower coal prices, falling 13.7 percent by 2020 and, on the other, much larger natural gas prices, growing 17.3 percent by 2020. As a result, we observe a 20.0 percent growth in the demand for coal and a drop in the demand for natural gas of 12.1 percent. The increase in natural gas prices contributes, in a very important way, to the 11.6 percent increase in investment in wind energy infrastructure, corresponding to an accumulated increase in the stock of wind turbines of 2.5 percent in 2020 and of 9.6 percent in 2050. Similarly, investment in hydroelectric energy infrastructures increases by 11.4 percent in 2020 leading a 9.7 percent increase in the stock by 2050 . Oil demand falls by 0.8 percent due to more limited technological substitution possibilities and smaller crude oil price movements. In this scenario, the shift to coal, and to a lesser extent to renewable energies, is much more dramatic than in the DOE-US price scenario. 
Figure 4 Energy Sector Impacts

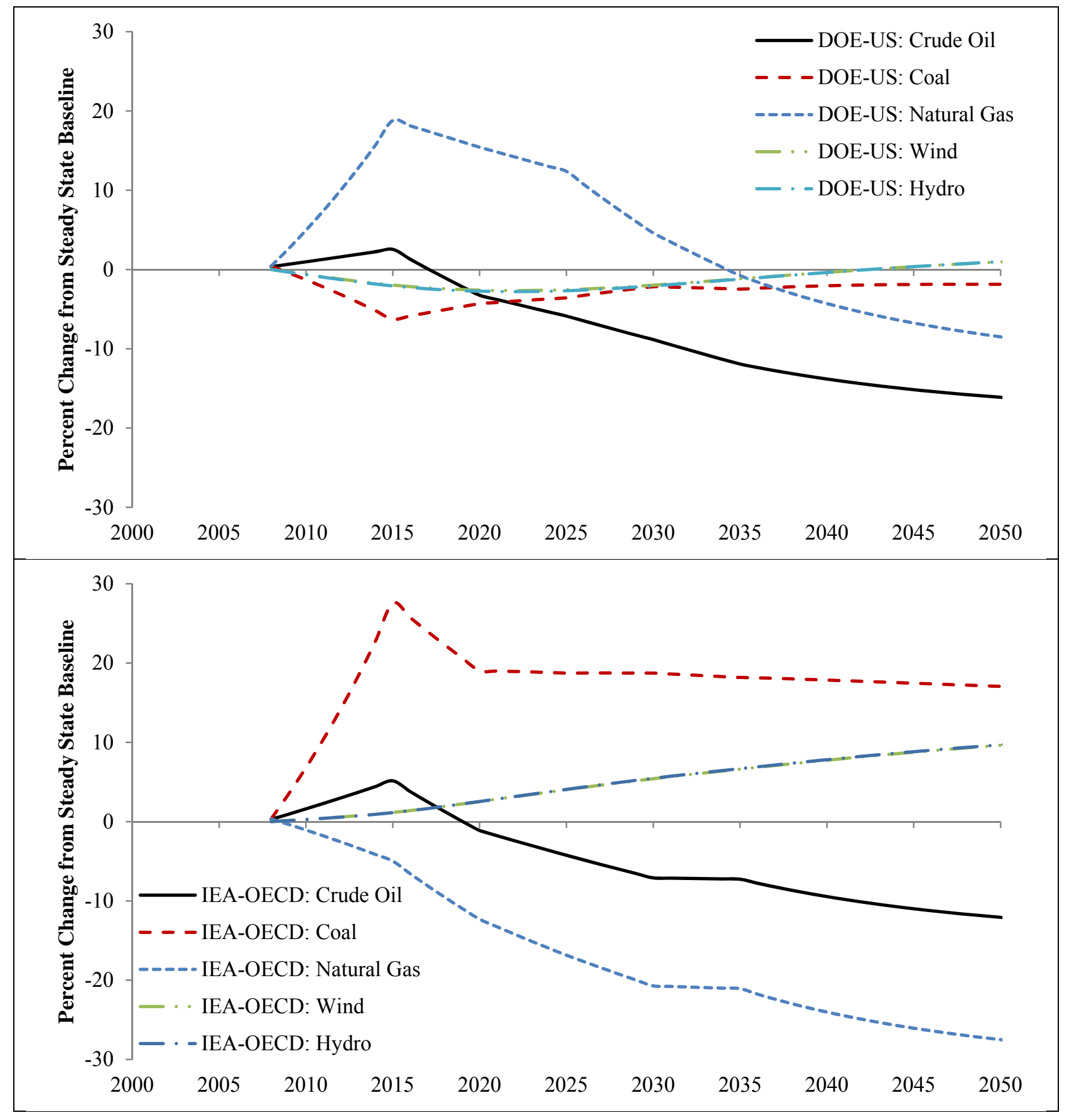




\subsection{The Macroeconomic Impact}

The macroeconomic impact of fossil fuel prices is fundamentally defined by the total change in energy system costs as opposed to the fuel mix in the energy system. As such, although the energy system effects differ substantially across the two fuel price scenarios, the economic and budgetary impacts share many common features. Because the firms' changes to the energy mix drive very similar changes in the composite energy price index between the two scenarios, the economic impacts are similar. Higher fuel prices and larger expenditures on energy inputs have a negative impact on the firms' net cash flow. Accordingly, businesses reduce private investment by 1.4 percent and 3.6 percent in the DOE-US scenario and by 1.3 percent and 3.0 percent in the IEA-OECD scenario in 2020 and in 2050, respectively. This is consistent with the larger share of wind and hydroelectric investment in the IEA-OECD scenario than in the DOE-US scenario. The reduction in private investment drives down the stock of private capital which in turn has a negative impact on economic growth. Over the long term, energy price increases have a negative impact on employment as well, despite short term employment gains in both the DOE-US and IEA-OECD scenarios. The smaller reductions in private capital and employment than in energy consumption suggests that with growing fuel prices firms substitute capital and especially labor for energy inputs.

Given the impact of fuel prices on the private inputs (which as we will see next section is mirrored by reductions in public and human capital investment), it is no surprise that higher fuel prices, driven primarily by higher oil prices, have a negative impact on GDP. In 2050, GDP falls by 1.9 percent in the DOE-US scenario while in the IEA-OECD scenario GDP falls by 1.6 percent. Short term reductions in fossil fuel prices stimulate a marginal increase in economic activity early in the model horizon in both scenarios. The short term increase in GDP in 2020 in 
the DOE-US scenario is entirely driven by falling natural gas prices while that in the IEA-OECD scenario results from dropping crude oil and coal prices.

The feedback between domestic demand, production and income defines the impact of fuel prices on private consumption. The net effect of this process is a reduction in private consumption of 1.3 percent in the DOE-US scenario and 1.1 percent in the IEA-OECD scenario. Consumption smoothing behavior by households implies that these reductions are relatively constant throughout the model horizon.

The net effect of fuel price increases on the trade balance depends on the response of non-energy demand. Expenditure on fossil fuels increases by 2.3 percent in the DOE-US scenario and 1.5 percent in the IEA-OECD in 2020 and up to 19.5 percent and 15.3 percent in 2050, respectively, which places positive pressure on the trade balance. This increase in fossil fuel expenditure, however, is offset by reductions across the board in domestic final demand. As a result, the net effect of higher energy prices on foreign debt is negative. Although foreign debt as a fraction of the GDP falls, over the long term these remain at 54.2 percent in the DOE-US scenario and 62.6 percent in the IEA-OECD price scenario.

\subsection{On the Budgetary Impact}

The reduction in economic activity levels due to the increasing expenditure on fossil fuels affects the size of the tax bases and public sector tax receipts. Contracting tax bases in the DOEUS and IEA-OECD scenarios drive a 0.4 percent reduction in tax revenue by 2020 and of 2.0 percent and 1.7 percent in 2050 , respectively. These changes are driven primarily by changes in VAT tax revenues, the largest source of public revenues. In absolute terms, the reduction in revenues associated with fuel price increases is led by a reduction in VAT revenue of 1.8 percent in the DOE-US scenario and 1.5 percent in the IEA-OECD. These changes in turn are directly 
related to the changes in private consumption, the largest component of its tax base. The falling share of VAT receipts in both scenarios is accompanied by increasing shares for social security contributions, reflective of the shift towards employment in production.

On the expenditure side, the public sector optimally adjusts its spending patterns in response to fuel price variations. Total public expenditure falls in the long term by 3.3 percent and 2.8 percent in the DOE-US and IEA-OECD scenarios while public consumption itself falls by 4.3 percent and 3.6 percent, respectively. Equally important, in the long-term, public capital investment falls by 4.8 percent in the DOE-US scenario and by 4.1 percent in the IEA-OECD scenarios while public investment in human capital falls by 0.9 percent and 0.7 percent, respectively. This reduction in public investment activities further reinforces the negative effect

\section{Figure 5 Budgetary Impact}

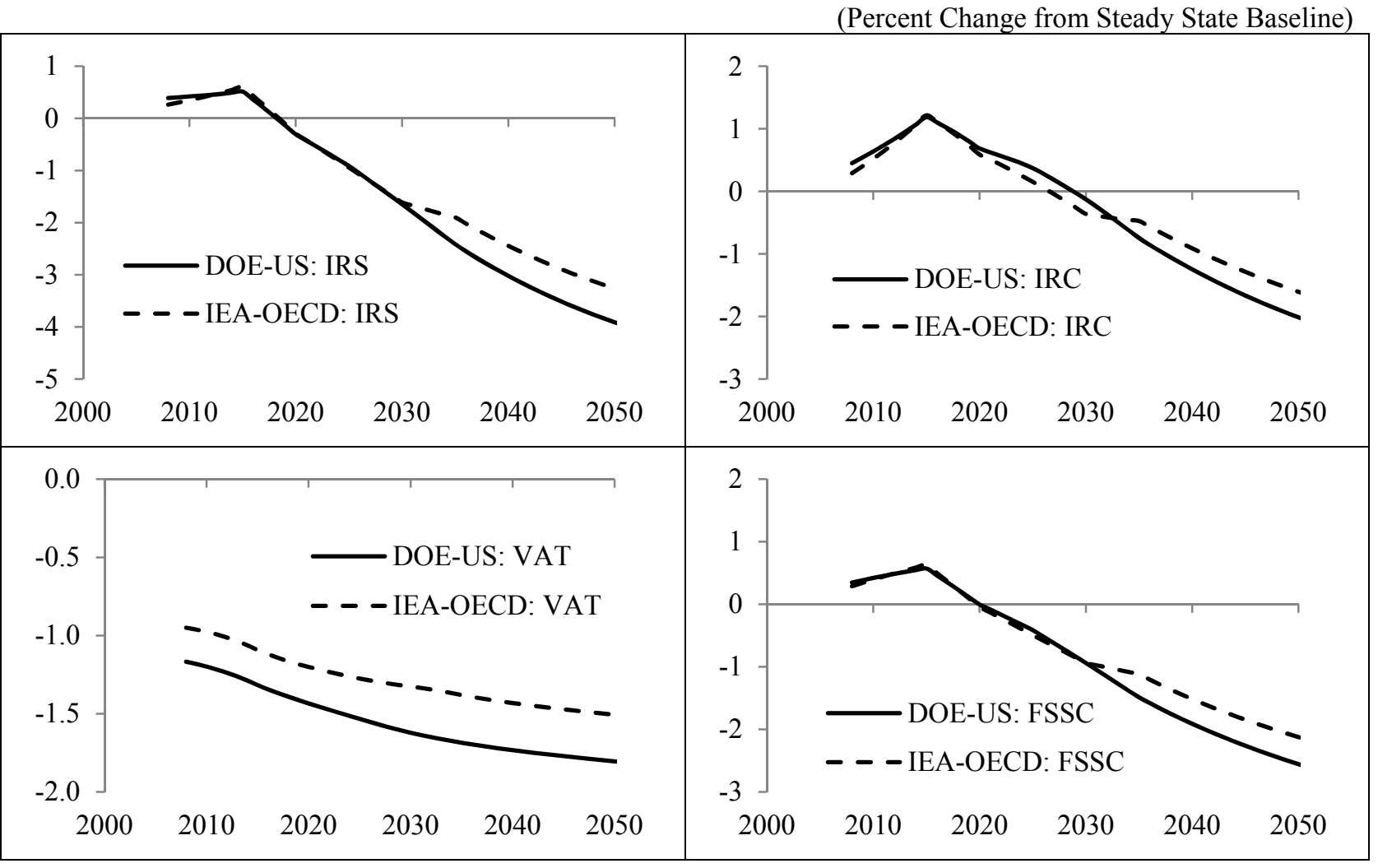


of declining private inputs on production activities and has a negative impact on economic performance.

Overall, despite tax revenue losses, the reduction in expenditure levels reduces public debt levels in 2020 by 9.3 percent and 8.1 percent in the DOE-US and IEA-OECD scenarios and by 22.6 percent and 19.3 percent by 2050 . This leads to public-debt to GDP ratios in the long term of 66.4 percent in the DOE-US scenario and 69.2 percent in the IEA-OECD scenario. The optimal government response to the increasing opportunity cost of public fund is instrumental in driving positive budgetary effects. Absent these, the contracting tax bases yield an increase in public debt levels. It is important to highlight that our focus on the long term budgetary effects of increasing fuel prices suggests equilibrium responses and not fluctuations in debt levels spurred by business cycle fluctuations. Given the very low cost of financing since the adoption of the Euro it is not unreasonable to assume that interest rates do not fall with the lower levels of debt.

\subsection{On the Impact of Incentives for Renewable Energy on the Economic and Budgetary Impact of Fossil Fuel Prices}

Policies to promote the deployment of renewable energies are designed to ensure the security of energy supply, reduce the environmental impacts of the energy system and limit the exposure of the domestic economy to international shocks in energy markets. To explore the potential for renewable energy policies to limit domestic exposure to international fuel price movements, we examine the impact of a renewable energy investment tax credit on the economic and budgetary impact of the fossil fuel price scenarios. The renewable energy investment tax credit is equal to half of the value of the investment and is available for both wind and hydroelectric energy investment activities. Over the long run, wind energy infrastructure is 72.3 percent larger in the DOE-US scenario and 86.9 percent larger in 2050 in the IEA-OECD 


\section{Figure 6 On the Impact of a Renewable Energy Investment Tax Credit}

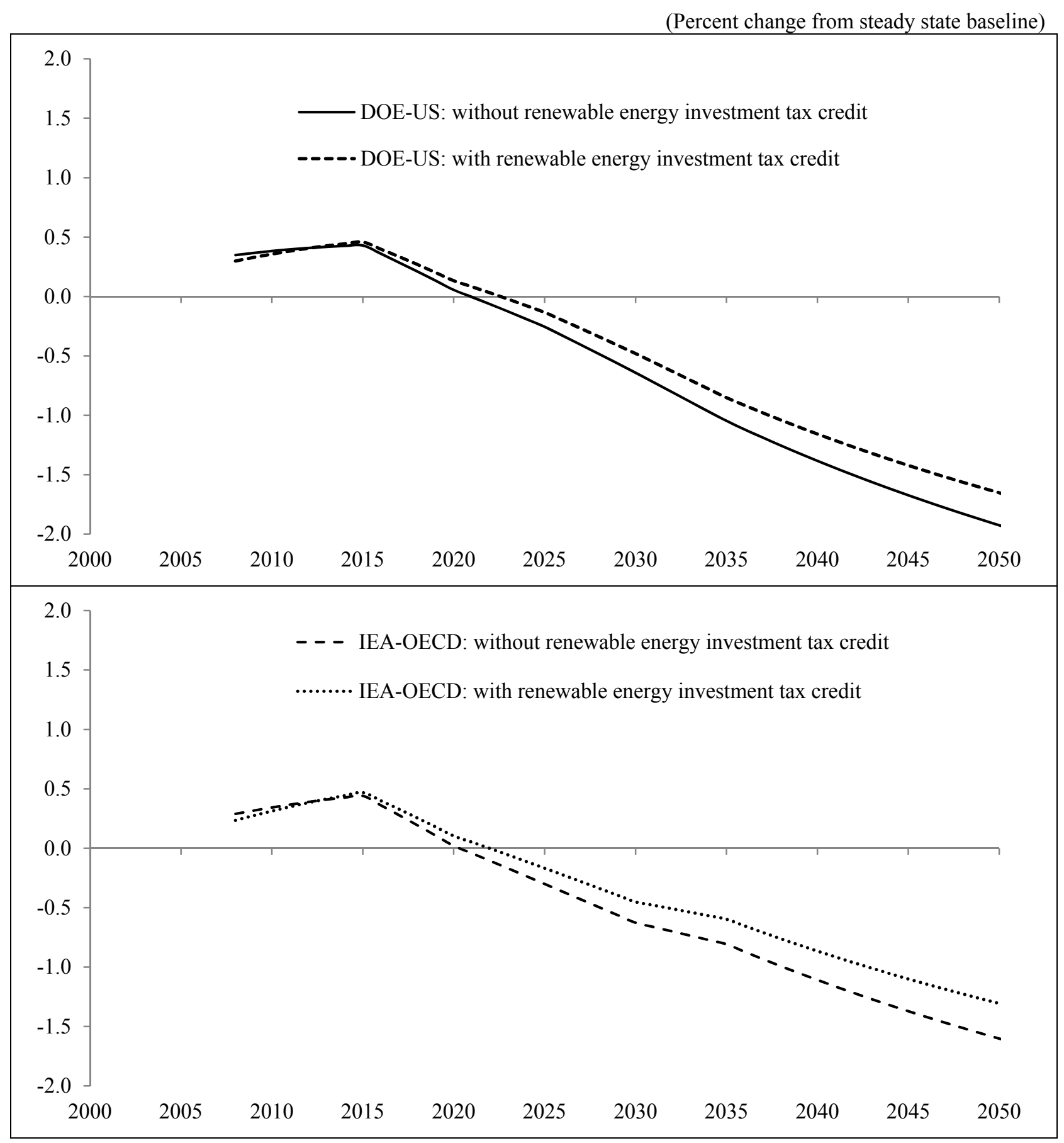


scenario and hydroelectric energy infrastructure is 72.9 percent and 87.7 percent larger in the DOE-US and IEA-OECD scenarios relative to steady state baseline levels, respectively.

The renewable energy investment tax credit has the effect of mitigating the impact of fossil fuel price increases on economic growth and activity levels. GDP falls by 1.7 percent in the DOE-US and by 1.3 percent in the IEA-OECD price scenario in 2050 . This is a 14.2 percent reduction in the economic impact in the DOE-US price scenario and 18.5 percent reduction in the IEA-OECD price scenario. Public debt to GDP levels, however, are 2.3 percentage points higher in the DOE-US price scenario and 2.5 percentage points higher in the IEA-OECD price scenario. This results from the increase in tax expenditure for the investment tax credit and a smaller overall reduction in public expenditure levels and is partially offset by a smaller contraction in economic activity.

\section{Sensitivity Analysis with respect to Model Structure and Key Model Parameters}

It is widely recognized in the literature that the elasticity of substitution between value added and energy as well as among energy inputs play a significant role in a general equilibrium analysis of energy-related matters [see Jacoby et al. (2006), Wissema and Dellink (2007), and Schubert and Turnovsky (2010)]. Here, we start by analyzing how sensitive our results are to the specification of these parameters. Simulation results are reported on Table 5. In general, changes in energy demand due to higher fuel prices are significantly amplified by a greater elasticity of substitution between energy and value added and lower elasticity of substitution among energy inputs. Changes in the economic impact as well as the budgetary impact are, however, less pronounced across different elasticity of substitution assumptions, in particular for that among different energy inputs. 
Table 5: Sensitivity Analysis with respect to the Elasticities of Substitution

(Percent deviation from steady state baseline in 2050)

Elasticity of Substitution between Value Added and Energy

\begin{tabular}{|c|c|c|c|}
\hline Elasticity of Substitution & Energy & GDP & Public Debt \\
\hline \multicolumn{4}{|c|}{ DOE-US } \\
\hline 0.2 & -0.42 & -1.77 & -23.47 \\
\hline 0.4 & -6.31 & -1.92 & -22.64 \\
\hline 1.0 & -21.83 & -2.31 & -20.38 \\
\hline \multicolumn{4}{|c|}{ IEA-OECD } \\
\hline 0.2 & 4.43 & -1.47 & -19.91 \\
\hline 0.4 & -0.77 & -1.60 & -19.33 \\
\hline 1.0 & -14.74 & -1.95 & -17.71 \\
\hline \multicolumn{4}{|c|}{ Elasticity of Substitution between Crude Oil and other Energy Sources } \\
\hline Elasticity of Substitution & Energy & GDP & Public Debt \\
\hline \multicolumn{4}{|c|}{ DOE-US } \\
\hline 0.2 & -8.82 & -1.94 & -22.84 \\
\hline 0.4 & -6.31 & -1.92 & -22.64 \\
\hline 1.0 & 1.58 & -1.88 & -22.01 \\
\hline \multicolumn{4}{|c|}{ IEA-OECD } \\
\hline 0.2 & -1.40 & -1.60 & -19.36 \\
\hline 0.4 & -0.77 & -1.60 & -19.33 \\
\hline 1.0 & 1.13 & -1.60 & -19.24 \\
\hline
\end{tabular}

Overall, ignoring endogenous public sector decisions and endogenous long-term growth would lead to a serious misrepresentation of the effects on fuel prices on economic activity, GDP and foreign debt position, and on the public budget. The fiscal consolidation gains only materialize in the presence of optimal reductions in public sector expenditure. This reduction is optimal, despite negative welfare effects, due to the increasing opportunity cost of public funds. In addition, the required reduction in public expenditure is greater than may have been projected absent accounting for the important feedbacks among growth and the public sector account. This is because the contraction in economic activity due to increasing fuel prices can be expected to 
apply greater pressure on the tax bases, reducing revenue and aggravating the budgetary situation. For this reason, public consumption activities must be the target of fiscal consolidation policy efforts that focus too much on reductions in productive public sector investment activity will compound the debt increase. Note that this is consistent with a marginal reduction in public investment activities due to the increasing opportunity cost associated with public funds.

Endogenous growth and endogenous public sector behavior are key features of our model. Table 6 presents the sensitivity of our results to these aspects of the model. Without the endogenous public spending decisions, we assume that public consumption and investment grow at the baseline steady state growth trajectory for the economy. A sensitivity analysis was conducted allowing for public consumption and investment to scale with output and the results suggest that this proportional adjustment captures less than half of the effects associated with endogenous growth. Results are available upon request. The exogenous growth trajectory we adopt is indicative of political constraints on changing spending patterns. The absence of endogenous growth coupled with exogenous public sector behavior greatly affects the evaluation of the impact of fuel prices. Exogenous decisions imply higher levels of investment spending which leads to substantially smaller output losses in the long term - the measured output losses under exogenous public sector decision would be around 40 percent of the levels identified under our central modeling assumptions. This reduction in the observed GDP loss comes together with a marginal improvement in the trade deficit and the foreign debt position, substantially lower than the one identified in the central case - the observed improvements shrink by a factor of seven. Tax revenues decline by a smaller amount under exogenous public sector decisions. In this case, however, lower tax revenues would directly translate into higher deficits and we would 
project increases in the public debt to GDP position, not the reduction identified under our central modeling assumptions.

In concluding this sensitivity analysis section, it is important to highlight that the order of magnitude of the changes in the economic and budgetary results due to differences in the elasticities of substitution - a widely understood effect - pale in comparison with the changes generated by the endogenous growth mechanisms and endogenous public sector behavior effects largely ignored in the literature. This is in sharp contrast to the notion that the economic effect of oil is driven by the share of oil in production and the elasticity of substitution between oil and other inputs [see, Schubert and Turnovsky (2010)].

Table 6: Sensitivity Analysis with respect to the Model Structure

(Percent deviation from steady state baseline in 2050)

\begin{tabular}{|c|c|c|c|}
\hline & Energy & GDP & Public Debt \\
\hline & \multicolumn{3}{|c|}{ DOE-US } \\
\hline Central Modeling Assumptions & -6.31 & -1.92 & -22.64 \\
\hline Exogenous Public Consumption (1) & -6.28 & -1.89 & 5.89 \\
\hline Exogenous Public Investment (2) & -5.54 & -1.10 & -16.13 \\
\hline \multirow[t]{2}{*}{ Exogenous Public Sector (1) $+(2)$} & -5.52 & -1.08 & 9.05 \\
\hline & \multicolumn{3}{|c|}{ IEA-OECD } \\
\hline Central Modeling Assumptions & -0.77 & -1.60 & -19.33 \\
\hline Exogenous Public Consumption (1) & -0.74 & -1.57 & 4.66 \\
\hline Exogenous Public Investment (2) & -0.08 & -0.91 & -13.87 \\
\hline Exogenous Public Sector (1) + (2) & -0.06 & -0.89 & 7.32 \\
\hline
\end{tabular}




\section{Summary and Concluding Remarks}

In this paper, we examine the economic and budgetary impacts of fossil fuel prices using a dynamic general equilibrium model of the Portuguese economy which highlights the mechanisms of endogenous growth and includes a detailed modeling of the public sector. Our simulation results highlight several important dimensions to the relationship between energy prices and economic performance. First, while relative energy prices play a substantial role in shaping the energy sector, the most important determinant of the economic impacts of the exogenous price shocks is the change in the firms' energy bill. Second, fuel prices, by affecting economic performance, affect fiscal consolidation efforts. This paper highlights that the behavior of the public sector is not innocuous, leading to our third point. Government behavior in response to rising fuel prices has a substantial impact on the potential trade-off that exists between convergence to EU standards of living and fiscal consolidation. Absent reductions in public consumption, rising energy prices can increase public debt levels through contracting tax bases. In addition, to the extent that the public sector can avoid reductions in public investment activities, we will observe smaller GDP losses and more substantial public debt improvements with the austerity package. Finally, we find that renewable energy policies may contribute to limiting the exposure of the domestic economy to exogenous fuel price shocks - a very substantial incentive policy would reduce the economic impact of fossil fuel prices far less than active government investment in public capital and human capital.

Increasing fuel prices, consistent with the DOE-US and the IEA-OECD fuel price scenarios, both dominated over the long term by increasing oil prices, lead to an increase in firms' operating costs which reduces energy consumption, employment and private investment, while shifting the input mix towards labor and capital. Despite very substantial differences in 
their implications for the energy sector, the two price scenarios yield similar overall changes in the composite energy price changes which drives their macroeconomic and budgetary impact. These changes lead to a long term drop of 1.9 percent in GDP by 2050 in the DOE-US scenario and 1.6 percent in the IEA-OECD scenario. Although the value of fossil fuel imports increases substantially over time, the contraction of economic activity due to higher fuel prices leads to an overall improvement in the foreign account position. This is consistent with the recent studies on the effect of permanent increases in oil prices [see, for example, Schubert (2009)]. Finally, higher fuel prices have an important impact on the public sector account and public investment activities. Contracting tax bases reduce revenues, led by reductions in VAT revenues, while a reduction in public spending, and public investment in particular, further compounds the longterm output and employment losses. These are, however, consistent with an optimally shrinking public sector which leads to a reduction in the deficit and lower public debt to GDP levels.

Fuel prices, by affecting economic performance, directly affect the pursuit of policies to promote long term growth and convergence to EU standards of living. Indeed, our results indicate that higher fuel prices have a negative effect on long-term growth, and likely on real convergence. In addition, fuel prices have a pronounced impact on the public sector and thereby important policy implications in the context of the Stability and Growth Programs in general and the current quest for fiscal consolidation and austerity plans in particular. Two important points emerge. First, through their negative impact on economic performance, increasing fuel prices reduce tax revenues, particularly once the feedbacks with public investment are taken into account. Second, the public sector optimally reduces investment activities. While this further compounds output losses, it alleviates pressure on the budget. Accordingly, increasing fuel prices 
create an important policy trade off in that they can contribute to reducing the public deficit while hindering real convergence.

The endogeneity of public sector decisions plays an important role in determining the impact of increasing fuel prices. Specifically, tax revenue losses reduce the funds available for productive public sector activities. This affects the level of economic activity and, as a result, the public sector account. By ignoring these feedbacks, exogenous growth assumptions result in substantially smaller GDP losses and lower foreign debt to GDP and public debt to GDP gains in the presence of increasing fuel prices. In particular, in the absence of changes in public expenditure behavior, tax revenues fall substantially less than they otherwise do which reflects a smaller loss in the tax base. In an environment of exogenous public spending decisions characterized by great inertia in reducing spending, however, any changes in tax revenues translate directly into changes in the public deficit. Accordingly, with exogenous public spending, following the status quo patterns one would project a deterioration of the public debt to GDP position with increasing fuel prices while we actually project an improvement.

From a methodological perspective, if the feedback mechanisms on public spending are ignored, any budgetary projections are liable to seriously misrepresent the effects of higher fuel prices. Namely, that higher fuel prices may actually lead to optimal spending adjustments which can improve the budgetary situation. From a policy perspective, increasing fuel prices, which would require an optimal reduction in public spending, together with the ongoing inability to adjust spending in light of new budgetary conditions, have certainly contributed to the current budgetary woes.

More importantly, increasing fuel prices will require even more significant financial consolidation efforts under the current EU and IMF austerity plans if budgetary consolidation is 
to actually be achieved. Failure to engage in strong fiscal restraint, optimal in the presence of tax revenue losses due to higher fossil fuel prices, i.e., ignoring the impact of fuel prices in this context, may prove to be the best recipe for missing budgetary consolidation targets.

This paper opens several interesting avenues for future research and should be regarded as just the starting point of a new line of inquiry. An analysis of the sectoral effects of oil price shocks would provide for the distributional implications of policies and their political economy ramifications. In this context, it may further be important to consider the effects of price mark up for electric power consistent with a monopoly structure natural to transmission and impact of opening up of distribution and production to competition. An energy process and activity focus for the model could allow for an analysis of policies that focus on promoting technological development and deployment. Along these lines, an analysis of the potential contribution of renewable energy policies to reducing the negative environmental externalities associated with fossil fuel consumption would be a natural extension to this paper. Given the importance of public debt and present concerns regarding public debt financing in Portugal, future research should incorporate endogenous interest rate mechanisms. Finally, due to the importance of employment concerns in the current policy environment, an endogenous unemployment rate would allow for a more detailed analysis of the labor market implications of policies.

To conclude, it should be mentioned that although the results in this paper are directly relevant for policy making in Portugal, their interest and applicability is far from parochial. Concerns over economic growth and fiscal sustainability are at the forefront of policy discussion in many countries. Furthermore, EU countries such as Greece and Ireland are facing similar budgetary problems and equally difficult austerity plans. Many of the lessons presented here and applicable to Portugal can easily be used to inform policy making in these countries as well. 


\section{Bibliography}

1. Amador, J. (2010) Energy Production and Consumption in Portugal: Stylized Facts. Economic Bulletin and Financial Stability Report Articles, Banco de Portugal, Economics and Research Department.

2. Backus, D., Crucini, M. (2000) Oil prices and the terms of trade. Journal of International Economics. 50(1): 185-213.

3. Bergman, L (2005). CGE modeling of environmental policy and resource management. In Handbook of Environmental Economics (Volume 3), Karl-Göran Mäler and Jeffery R. Vincent, ed., 1273-1306. Amsterdam: North Holland.

4. Borges, A., Goulder, L. (1984) Decomposing the impact of higher energy prices on longterm growth, in Scarf, H. E., and J. B. Shoven (eds.), Applied General Equilibrium Analysis, Cambridge University Press, Chapter 8.

5. Brown, S., Yücel, M. (2002) Energy Prices and Aggregate Economic Activity: An Interpretative Survey. Quarterly Review of Economics and Finance. 42(2): 193-208.

6. Bruno, M., Sachs, J. (1985) Economics of worldwide stagflation. Cambridge, MA, Harvard University Press.

7. Carraro, C., De Cian, E., Tavoni, M., (2009) Human capital formation and global warming mitigation: evidence from an integrated assessment model. CESifo Working Paper 2874, Munich.

8. Conrad, K. (1999) Computable general equilibrium models for environmental economics and policy analysis. In Handbook of Environmental and Resource Economics Jeroen van den Bergh, ed., Cheltenham: Edward Elgar.

9. Department of Energy, United States. 2010. Annual Energy Outlook 2010: with projections to 2035. DOE-US/EIA-0383(2010).

http://www.eia.DOE-US.gov/oiaf/aeo/pdf/0383(2010).pdf

10. Esteves, P., Neves, P. (2004) Oil Prices and the Economy. Bank of Portugal, Economic Bulletin December 2004.

11. Esteves, P., Coimbra, C., (2004) Oil Prices Assumptions in Macroeconomic Forecasts: Should we Follow Futures Market Expectations. Bank of Portugal, WP 4-04.

12. European Commission. (2010) European Economic Forecast: Autumn 2020. European Economy. Commission Staff Working Document.

13. European Commission. (2012) Statistical annex of the European economy. Directorate General for Economic and Financial Affairs (ECFIN). Spring 2012 European Economy. Brussels. 
14. Hamilton, J. (2003) What is an oil shock? Journal of Econometrics. 113(2): 363-398.

15. Hamilton, J. (2009) Understanding crude oil prices. The Energy Journal. 30(2): 179-206.

16. He, Y., Wang, S., Keung Lai, K. (2010) Global economic activity and crude oil prices: A cointegration analysis. Energy Economics. 32(4): 868-876.

17. Jacoby, H., Reilly, J., McFarland, J., Paltsev, S. (2006) Technology and Technical Change in the MIT EPPA Model. Energy Economics. 28(5-6): 610-631.

18. Jorgenson, D. (1998) Growth. Volume 2: Energy, the Environment and Economic Growth, Cambridge, Mass., MIT Press.

19. Koetse, M., Henri, L., de Groot, R., Florax, J. (2008) Capital-energy substitution and shifts in factor demand: A meta-analysis. Energy Economics 30(5), 2236-2251.

20. Korhonen, I., Ledyaeva, S. (2010) Trade linkages and macroeconomic effects of the price of oil. Energy Economics. 32(4):848-856.

21. Manne A. Richels, R. (1992) Buying Greenhouse Insurance - the Economic Costs of Carbon Dioxide Emission Limits. MIT Press, Cambridge.

22. Paltsev, S., Reilly, J., Jacoby, H., Eckaus, R., McFarland, J., Sarofim, M., Asadoorian, M., Babiker, M. (2005) The MIT Emissions Prediction and Policy Analysis (EPPA) Model: Version 4. MIT Joint Program on the Science and Policy of Global Change Report 125.

23. Pereira, A., Rodrigues, P. (2002) On the impact of a tax shock in Portugal. Portuguese Economic Journal. 1(3): 205-236.

24. Pereira, A., Rodrigues, P. (2004) Strategies for Fiscal Reform in the Context of the EMU: The Case of Portugal. Review of Development Economics. Vol. 8(1): 143-165.

25. Pereira, A., Rodrigues, P. (2007) Social Security Reform in Portugal: A Dynamic General Equilibrium Analysis. Portuguese American Development Foundation, Lisbon.

26. Pereira, A., Pereira, R. (2011) Marginal Abatement Cost Curves and the Budgetary Impact of $\mathrm{CO}_{2}$ Taxation in Portugal. College of William and Mary Economics Working Paper 105.

27. Pereira, A., Pereira, R. (2013) Environmental Fiscal Reform and Fiscal Consolidation: The Quest for the Third Dividend in Portugal. Public Finance Review (Forthcoming).

28. Portuguese Directorate General for Geology and Energy. (2012) Factura Energética. Direcção Geral de Energia e Geologia. Ministerio da Economia. www.dgeg.pt

29. Portuguese Ministry of Finance. (2012) Estatistica das Financas Publicas. Gabinete de Planeamento, Estrategia, Avaliacao e Relacoes Internacionais, Ministerio das Financas.http://www.gpeari.min-financas.pt/ 
30. Roeger W. (2005) International oil price changes: impact of oil prices on growth and inflation in the EU/OECD. International Economics and Economic Policy Journal. 2(1): 1532.

31. Schubert, S., (2009) Dynamic Effects of Oil Price Shocks and their Impact on the Current Account. MPRA Paper 16738, University Library of Munich, Germany.

32. Schubert, S., Turnovsky, S. (2010) The impact of oil prices on an oil-importing developing economy. Journal of Development Economics. 94(1):18-29.

33. Sousa, T. (2011). International macroeconomic interdependence and imports of oil in a small open economy. Portuguese Economic Journal. 10(1): 35-60.

34. Tang, W., Libu, W., Zhang, Z. (2010) Oil Price Shocks and their Short and Long-term Effects on the Chinese Economy. Energy Economics. 32(Supplement 1): S3-S14.

35. Wissema, W., Dellink, R. (2007) AGE analysis of the impact of a carbon energy tax on the Irish economy. Ecological Economics. 61(4): 671-683.

36. Xepapadeas, A. (2005) Economic growth and the environment, Handbook of Environmental Economics, in: K. G. Mäler \& J. R. Vincent (ed.), Handbook of Environmental Economics, edition 1, volume 3, chapter 23, 1219-1271. 
Table A1: Economic and Budgetary Impact of the DOE-US Fossil Fuel Price Scenario

( Percent deviations from steady state baseline unless otherwise indicated)

\begin{tabular}{|c|c|c|c|c|c|}
\hline & 2010 & 2020 & 2030 & 2040 & 2050 \\
\hline Composite Price Level & 97.9 & 102.0 & 114.6 & 128.0 & 134.4 \\
\hline \multicolumn{6}{|c|}{ Energy } \\
\hline Primary Energy & 0.38 & -1.33 & -3.94 & -5.74 & -6.31 \\
\hline Fossil Energy & 1.24 & -0.23 & -5.56 & -10.26 & -12.44 \\
\hline Crude Oil & 0.97 & -2.91 & -8.88 & -13.80 & -16.11 \\
\hline Coal & -1.33 & -4.44 & -2.35 & -2.06 & -1.86 \\
\hline Natural Gas & 5.08 & 15.47 & 4.82 & -4.25 & -8.48 \\
\hline Wind Energy Infrastructure & -0.76 & -2.57 & -1.96 & -0.36 & 0.97 \\
\hline Hydroelectric Energy Infrastructure & -0.80 & -2.71 & -2.05 & -0.38 & 0.98 \\
\hline \multicolumn{6}{|c|}{ Macroeconomic } \\
\hline Growth Rate (Percent Change over Previous Period) & 1.78 & 1.69 & 1.68 & 1.70 & 1.71 \\
\hline GDP & 0.38 & 0.07 & -0.64 & -1.38 & -1.92 \\
\hline Consumption & -1.22 & -1.22 & -1.23 & -1.25 & -1.26 \\
\hline Investment & 0.05 & -1.35 & -2.49 & -3.15 & -3.55 \\
\hline Private Capital & 0.02 & -0.25 & -0.95 & -1.75 & -2.42 \\
\hline Investment Wind Energy & -9.42 & -3.81 & 2.56 & 4.22 & 4.29 \\
\hline Investment Hydroelectric Energy & -9.53 & -3.91 & 2.50 & 4.14 & 4.18 \\
\hline Labor Demand & 0.70 & 0.54 & 0.13 & -0.29 & -0.57 \\
\hline Energy Imports & -0.78 & 2.28 & 9.82 & 16.62 & 19.51 \\
\hline Foreign Debt (percent of GDP) & 104.20 & 86.58 & 70.55 & 59.87 & 54.18 \\
\hline Foreign Debt & -3.69 & -19.99 & -34.80 & -44.66 & -49.93 \\
\hline \multicolumn{6}{|c|}{ Public Sector } \\
\hline Public Debt (percent of GDP) & 84.24 & 77.82 & 72.20 & 68.47 & 66.37 \\
\hline Public Debt & -1.81 & -9.30 & -15.85 & -20.20 & -22.64 \\
\hline Total Expenditure & -3.04 & -3.19 & -3.26 & -3.27 & -3.28 \\
\hline Public Consumption & -4.85 & -4.78 & -4.61 & -4.43 & -4.31 \\
\hline Public Investment & -1.40 & -2.62 & -3.65 & -4.30 & -4.75 \\
\hline Human Capital Investment & -0.69 & -0.75 & -0.80 & -0.84 & -0.88 \\
\hline Public Capital & -0.08 & -0.48 & -1.07 & -1.71 & -2.33 \\
\hline Human Capital & -0.01 & -0.03 & -0.06 & -0.08 & -0.11 \\
\hline Total Tax Revenue & -0.13 & -0.41 & -1.01 & -1.61 & -2.01 \\
\hline Personal Income Tax & 0.42 & -0.27 & -1.65 & -3.02 & -3.91 \\
\hline Corporate Income Tax & 0.64 & 0.72 & -0.13 & -1.24 & -2.01 \\
\hline Value Added Tax & -1.20 & -1.43 & -1.62 & -1.73 & -1.80 \\
\hline Social Security Contributions & 0.42 & 0.02 & -0.94 & -1.91 & -2.55 \\
\hline
\end{tabular}


Table A2: Economic and Budgetary Impact of the IEA-OECD Fossil Fuel Price Scenario

(Percent deviations from steady state baseline unless otherwise indicated)

\begin{tabular}{|c|c|c|c|c|c|}
\hline & 2010 & 2020 & 2030 & 2040 & 2050 \\
\hline Composite Price Level & 96.7 & 102.2 & 116.1 & 121.8 & 128.9 \\
\hline \multicolumn{6}{|c|}{ Energy } \\
\hline Primary Energy & 1.28 & 1.68 & -0.01 & -0.29 & -0.77 \\
\hline Fossil Energy & 2.12 & 0.97 & -4.58 & -7.08 & -9.54 \\
\hline Crude Oil & 1.62 & -0.79 & -6.78 & -9.43 & -12.06 \\
\hline Coal & 7.04 & 19.98 & 18.67 & 17.86 & 17.06 \\
\hline Natural Gas & -1.08 & -12.05 & -20.31 & -23.99 & -27.49 \\
\hline Wind Energy Infrastructure & 0.35 & 2.54 & 5.41 & 7.74 & 9.62 \\
\hline Hydroelectric Energy Infrastructure & 0.34 & 2.54 & 5.46 & 7.81 & 9.68 \\
\hline \multicolumn{6}{|c|}{ Macroeconomic } \\
\hline Growth Rate (Percent Change over Previous Period) & 1.79 & 1.69 & 1.71 & 1.71 & 1.72 \\
\hline GDP & 0.34 & 0.03 & -0.61 & -1.11 & -1.60 \\
\hline Consumption & -1.01 & -1.02 & -1.03 & -1.04 & -1.05 \\
\hline Investment & 0.10 & -1.25 & -2.00 & -2.60 & -3.02 \\
\hline Private Capital & 0.02 & -0.22 & -0.83 & -1.44 & -2.01 \\
\hline Investment Wind Energy & 4.82 & 11.61 & 13.10 & 14.18 & 14.42 \\
\hline Investment Hydroelectric Energy & 4.49 & 11.39 & 12.87 & 13.97 & 14.20 \\
\hline Labor Demand & 0.60 & 0.43 & 0.05 & -0.21 & -0.47 \\
\hline Energy Imports & -1.37 & 1.54 & 9.02 & 12.07 & 15.33 \\
\hline Foreign Debt (percent of GDP) & 104.89 & 89.53 & 76.93 & 67.93 & 62.64 \\
\hline Foreign Debt & -3.06 & -17.26 & -28.90 & -37.22 & -42.11 \\
\hline \multicolumn{6}{|c|}{ Public Sector } \\
\hline Public Debt (percent of GDP) & 84.49 & 78.88 & 74.39 & 71.17 & 69.21 \\
\hline Public Debt & -1.53 & -8.06 & -13.30 & -17.05 & -19.33 \\
\hline Total Expenditure & -2.56 & -2.69 & -2.72 & -2.75 & -2.76 \\
\hline Public Consumption & -4.08 & -4.01 & -3.85 & -3.74 & -3.63 \\
\hline Public Investment & -1.16 & -2.27 & -3.01 & -3.60 & -4.05 \\
\hline Human Capital Investment & -0.58 & -0.63 & -0.67 & -0.71 & -0.74 \\
\hline Public Capital & -0.06 & -0.41 & -0.91 & -1.44 & -1.96 \\
\hline Human Capital & -0.01 & -0.03 & -0.05 & -0.07 & -0.09 \\
\hline Total Tax Revenue & -0.09 & -0.36 & -0.91 & -1.29 & -1.66 \\
\hline Personal Income Tax & 0.35 & -0.26 & -1.57 & -2.44 & -3.26 \\
\hline Corporate Income Tax & 0.53 & 0.62 & -0.31 & -0.91 & -1.60 \\
\hline Value Added Tax & -0.98 & -1.20 & -1.33 & -1.43 & -1.51 \\
\hline Social Security Contributions & 0.39 & -0.01 & -0.91 & -1.51 & -2.12 \\
\hline
\end{tabular}


Table A3: Economic and Budgetary Impact of the DOE-US Fossil Fuel Price Scenario with a Renewable Energy Investment Tax Credit valued at $50 \%$ of the Investment Volume

( Percent deviations from steady state baseline unless otherwise indicated)

\begin{tabular}{|c|c|c|c|c|c|}
\hline & 2010 & 2020 & 2030 & 2040 & 2050 \\
\hline \multicolumn{6}{|l|}{ Composite Price Level } \\
\hline \multicolumn{6}{|c|}{ Energy } \\
\hline Primary Energy & 3.43 & 14.37 & 19.74 & 22.65 & 24.73 \\
\hline Fossil Energy & 0.71 & -2.43 & -8.40 & -13.28 & -15.54 \\
\hline Crude Oil & 0.95 & -2.84 & -8.73 & -13.60 & -15.87 \\
\hline Coal & -2.78 & -10.60 & -10.91 & -11.68 & -11.99 \\
\hline Natural Gas & 3.49 & 8.04 & -4.36 & -13.66 & -17.92 \\
\hline Wind Energy Infrastructure & 8.14 & 33.76 & 52.57 & 64.87 & 72.30 \\
\hline Hydroelectric Energy Infrastructure & 8.49 & 34.90 & 53.80 & 65.86 & 72.90 \\
\hline \multicolumn{6}{|c|}{ Macroeconomic } \\
\hline Growth Rate (Percent Change over Previous Period) & 1.79 & 1.70 & 1.69 & 1.71 & 1.72 \\
\hline GDP & 0.35 & 0.14 & -0.48 & -1.16 & -1.65 \\
\hline Consumption & -1.04 & -1.05 & -1.06 & -1.07 & -1.08 \\
\hline Investment & 0.24 & -1.04 & -2.12 & -2.74 & -3.10 \\
\hline Private Capital & 0.04 & -0.14 & -0.74 & -1.46 & -2.07 \\
\hline Investment Wind Energy & 115.45 & 105.22 & 99.56 & 93.29 & 89.32 \\
\hline Investment Hydroelectric Energy & 115.00 & 104.01 & 98.14 & 91.91 & 87.96 \\
\hline Labor Demand & 0.62 & 0.51 & 0.15 & -0.23 & -0.49 \\
\hline Energy Imports & -1.09 & 1.14 & 8.26 & 14.85 & 17.66 \\
\hline Foreign Debt (percent of GDP) & 104.93 & 89.57 & 75.16 & 65.45 & 60.25 \\
\hline Foreign Debt & -3.02 & -17.22 & -30.54 & -39.51 & -44.32 \\
\hline \multicolumn{6}{|c|}{ Public Sector } \\
\hline Public Debt (percent of GDP) & 84.51 & 78.92 & 73.90 & 70.53 & 68.63 \\
\hline Public Debt & -1.50 & -8.01 & -13.87 & -17.79 & -20.01 \\
\hline Total Expenditure & -3.21 & -3.36 & -3.43 & -3.43 & -3.44 \\
\hline Public Consumption & -5.31 & -5.27 & -5.11 & -4.95 & -4.84 \\
\hline Public Investment & -1.04 & -2.16 & -3.14 & -3.75 & -4.17 \\
\hline Human Capital Investment & -0.59 & -0.64 & -0.69 & -0.73 & -0.76 \\
\hline Public Capital & -0.06 & -0.38 & -0.88 & -1.45 & -2.00 \\
\hline Human Capital & -0.01 & -0.03 & -0.05 & -0.07 & -0.10 \\
\hline Total Tax Revenue & -0.49 & -0.66 & -1.18 & -1.72 & -2.08 \\
\hline Personal Income Tax & 0.29 & -0.16 & -1.35 & -2.59 & -3.40 \\
\hline Corporate Income Tax & -4.77 & -4.28 & -4.85 & -5.70 & -6.31 \\
\hline Value Added Tax & -0.91 & -1.14 & -1.33 & -1.44 & -1.52 \\
\hline Social Security Contributions & 0.40 & 0.15 & -0.71 & -1.60 & -2.19 \\
\hline
\end{tabular}


Table A4: Economic and Budgetary Impact of the IEA-OECD Fossil Fuel Price Scenario with a Renewable Energy Investment Tax Credit valued at 50\% of the Investment Volume (Percent deviations from steady state baseline unless otherwise indicated)

\begin{tabular}{|c|c|c|c|c|c|}
\hline & 2010 & 2020 & 2030 & 2040 & 2050 \\
\hline \multicolumn{6}{|l|}{ Composite Price Level } \\
\hline \multicolumn{6}{|c|}{ Energy } \\
\hline Primary Energy & 4.24 & 17.84 & 25.25 & 30.37 & 33.03 \\
\hline Fossil Energy & 1.60 & -1.16 & -7.34 & -10.10 & -12.62 \\
\hline Crude Oil & 1.59 & -0.71 & -6.62 & -9.21 & -11.80 \\
\hline Coal & 5.45 & 12.45 & 8.41 & 6.35 & 5.02 \\
\hline Natural Gas & -2.49 & -17.57 & -27.20 & -31.41 & -34.94 \\
\hline Wind Energy Infrastructure & 9.04 & 39.71 & 63.17 & 77.84 & 86.90 \\
\hline Hydroelectric Energy Infrastructure & 9.42 & 41.12 & 64.78 & 79.09 & 87.66 \\
\hline \multicolumn{6}{|c|}{ Macroeconomic } \\
\hline Growth Rate (Percent Change over Previous Period) & 1.80 & 1.70 & 1.72 & 1.71 & 1.72 \\
\hline GDP & 0.31 & 0.12 & -0.43 & -0.86 & -1.30 \\
\hline Consumption & -0.82 & -0.83 & -0.84 & -0.84 & -0.85 \\
\hline Investment & 0.29 & -0.92 & -1.59 & -2.15 & -2.54 \\
\hline Private Capital & 0.05 & -0.10 & -0.60 & -1.13 & -1.64 \\
\hline Investment Wind Energy & 132.46 & 131.22 & 119.96 & 112.18 & 108.11 \\
\hline Investment Hydroelectric Energy & 131.88 & 130.06 & 118.23 & 110.44 & 106.38 \\
\hline Labor Demand & 0.51 & 0.41 & 0.08 & -0.15 & -0.38 \\
\hline Energy Imports & -1.68 & 0.30 & 7.30 & 10.14 & 13.31 \\
\hline Foreign Debt (percent of GDP) & 105.64 & 92.71 & 81.87 & 73.91 & 69.18 \\
\hline Foreign Debt & -2.37 & -14.31 & -24.33 & -31.69 & -36.06 \\
\hline \multicolumn{6}{|c|}{ Public Sector } \\
\hline Public Debt (percent of GDP) & 84.77 & 80.08 & 76.25 & 73.42 & 71.67 \\
\hline Public Debt & -1.20 & -6.67 & -11.13 & -14.42 & -16.46 \\
\hline Total Expenditure & -2.75 & -2.88 & -2.91 & -2.95 & -2.96 \\
\hline Public Consumption & -4.60 & -4.55 & -4.41 & -4.32 & -4.22 \\
\hline Public Investment & -0.77 & -1.77 & -2.45 & -3.01 & -3.42 \\
\hline Human Capital Investment & -0.47 & -0.52 & -0.55 & -0.58 & -0.61 \\
\hline Public Capital & -0.04 & -0.30 & -0.70 & -1.15 & -1.61 \\
\hline Human Capital & 0.00 & -0.02 & -0.04 & -0.06 & -0.08 \\
\hline Total Tax Revenue & -0.48 & -0.64 & -1.11 & -1.42 & -1.75 \\
\hline Personal Income Tax & 0.23 & -0.13 & -1.24 & -1.98 & -2.71 \\
\hline Corporate Income Tax & -5.29 & -5.00 & -5.50 & -5.80 & -6.33 \\
\hline Value Added Tax & -0.67 & -0.88 & -1.01 & -1.12 & -1.19 \\
\hline Social Security Contributions & 0.37 & 0.12 & -0.66 & -1.18 & -1.73 \\
\hline
\end{tabular}


